\title{
Smoke with Fire: Financial Crises and the Demand for Parliamentary Oversight in the European Union
}

\author{
Federica Genovese \\ University of Essex \\ fgenov@essex.ac.uk
}

\author{
Gerald Schneider \\ University of Konstanz \\ gerald.schneider@uni-konstanz.de
}

January 21, 2020*

\begin{abstract}
The handling of the 2008 financial crisis has reinforced the conviction that the European Union (EU) is undemocratic and that member states are forced to delegate overwhelming power to a supranational technocracy. However, European countries have engaged with this alleged power drift differently, with only a few member states demanding more parliamentary scrutiny of EU institutions. This article develops a political economy explanation for why only some states have enforced mechanisms to monitor the EU more closely. Our theory focuses on the role of the crisis and the impact of fiscal autonomy in countries outside and inside currency arrangements such as the European Economic and Monetary Union (EMU). We argue that, in the aftermath of a severe economic shock, member states outside the EMU possess more monetary and fiscal resources to handle the crisis. These would then demand oversight of EU decision-making if their fiscal sustainability depends on the Union. By contrast, Eurozone states that need policy changes cannot address the crisis independently or initiate reforms to scrutinize the EU. Hence, we argue that during the heated moments of severe economic downturns, parliaments in Eurozone countries discuss supranational supervision rarely. As these legislatures have nevertheless to give in to the popular demand for EU control, they express support for more EU supervision in the infrequent times of debate. We provide evidence for our theory with a cross-national analysis of EU oversight institutions, and a new original dataset of parliamentary debates during the Eurozone crisis. Our findings highlight the political consequences that financial nosedives have across the diverse membership of a supranational organization.
\end{abstract}

Keywords: EU politics; financial crises; Euro crisis; national parliaments; parliamentary scrutiny

\footnotetext{
* Previous versions of this paper were presented at the German Political Science Association and the Political Economy of International Organizations conference, as well as research seminars at the Free University Berlin, Leiden University, WZB, Tel Aviv University, University of St Gallen and the Institute for Advance Studies Toulouse. We thank conference and seminar participants, and Zareh Asatryan, Simon Hix, Martin Hoeppner, Kai Konrad, Rhea Molato, John Roemer, Thomas Sattler, Tal Sadeh, Enrico Spolaore, Aneta Spendzharova, Bernard Steunenberg, Jean Tirole and Vera Tröger for comments. We are grateful to Licia Biotti, Marlon Brandt, Alexander Bräunig, Claire Galesne, and Valerie Weber for research assistance and Thomas Winzen for sharing data. The paper also profited from comments by the guest editors and three anonymous reviewers.
} 
"There's no smoke without fire, Baby, baby you're a liar" - Duffy, Smoke with Fire

Scholars disagree over the conditions under which states press for policy reforms following a severe economic shock. A main proposition within the political economy literature suggests that governments do not launch reforms without the pressure from crises. Rodrik (1996, 27) argues in this vein "[t]hat policy reform should follow crises, then, is no more surprising than smoke following fire." Others, however, highlight the considerable delay with which many countries react to a severe economic downturn. These postponements can invoke, at least temporarily, the possibility of 'smoke-free fire': crises that do not lead to any credible demand for and de facto adoption of reforms (Alesina and Drazen 1991). Indeed, Greek decision makers stalled considerably at the onset of the Eurozone crisis before reluctantly accepting some of the measures designed by the European Union (EU), the European Central Bank (ECB) and the International Monetary Fund.

The crisis of the European Economic and Monetary Union (EMU) - the official name of the Eurozone - has reinvigorated the debate over the responsiveness of domestic institutions to international organizations. In Europe, this debate has been coupled by a discussion over the state of democracy in the European Union and its member states (Scharpf 2011; Schneider 2018). Several scholars believe that the organization's supranationalinfrastructure undermines the social fabric of its member states. Numerous public opinion studies claim that the Eurozone crisis has reduced trust in EU governments (Armingeon and Ceka 2015) and that this effect is particularly strong in the most affected countries (Foster and Frieden 2017). Additionally, political parties research has elucidated the link between the crisis, economic voting and the electoral success of populist parties across the continent (LeDuc and Pammett 2013).

Motivated by this debate, our paper adds a political economy framework to the growing literature on EU parliamentary institutions (Hagemann et al. 2019; Malang 2019; Rocabert et al. 2019), and specifically to how national parliaments in Europe have reacted to the recent crisis. Examining the reactions of the national legislatures across Europe, Auel and Höing (2014: 1192) identify "a large gap between the strongest and most active parliaments in the EU and the weakest, least active" (see also Winzen 2017). Yet, despite the growing evidence of Europeans' reactiveness to the crisis and the public demand for reforms, less research has focused on the political economy of parliamentary responses. 
Other works have uncovered the ways national parliaments have discussed the crisis and the supervision of the Eurozone crisis managers (e.g. Maatsch 2017; Puntscher Riekmann \& Wydra 2013; Rauh and de Wilde 2018). Here, we focus on structural economic reasons for why parliaments may have (a) adopted and (b) debated EU oversight. ${ }^{1}$

We advance an institutional constraint argument to explain the ways parliamentary chambers across the continent position themselves towards the EU during economic downturns. We start from the observation that EU member state parliaments, which are representations of domestic publics and aggregations of political parties, often struggle to provide credible and prompt solutions during a crisis, given the semi-integrated set up of the European Union (Mair 2009, Laffan 2014). So, despite public divisions over the monitoring of parliamentary affairs (Ruiz-Rufino and Alonso 2017) and party disagreements in the domestic chambers (Maatsch 2017; Wonka 2016), legislatures need to confront the EU supranational institutions as unitary actors in order to fulfill their representative purpose. ${ }^{2}$

We maintain that demand for increased parliamentary scrutiny of the EU varies between EMU members and non-members and depends on their possibility to react to the crisis with fiscal means (Fasone 2014; Hallerberg et al. 2018). As EMU outsiders possess more policy autonomy and can counter the negative effects of a financial meltdown with their own means, they have little interest in increasing oversight of the EU during a crisis. However, non-member states with significant debt - and hence with substantial fiscal policy constraints - are more sensitive to EU crisis management, as their ability to counteract the crisis crucially depends on the EU kick-starting the common market (Alesina and Giavazzi 2013). These countries would be more interested in overseeing EU decision-making while they engineer their domestic crisis management. Hence, the national parliaments in highly indebted non-Euro countries should be more likely to strengthen the oversight of the supranational decision-maker during a crisis.

Among Euro states, we expect only marginal adoptions of EU parliamentary oversight institutions during a crisis. Focusing on the recent past and the 2008 recession, we argue

\footnotetext{
${ }^{1}$ We refer to an increase in EU oversight as an expansion of institutional measures to oblige more reporting from Brussels. We use Winzen (2012)'s definition of oversight institutions, which cover parliamentary information rights including the right to receive Explanatory Memorandums, the basic institutional infrastructure for the processing of EU information (committee involvement and scrutiny reserve) as well as rights related to the enforcement of parliamentary positions (i.e. mandating rights).

${ }^{2}$ It is common in the literature to treat parliaments as unitary actors; see Winzen (2017) and Hallerberg et al. (2018).
} 
that parliaments in Euro members often did not engage in monitoring EU institutions closely due to the constraints generated by the common currency (Schimmelfennig 2015). At the same time, this does not imply that national parliaments were passive observers of the Euro crisis (Auel and Höing 2014). We hold that the parliaments of Euro members were actively involved in scrutinizing the supranational crisis management, but gave voice to these concerns strategically. The legislatures debated EU oversight when the crisis had not yet hit at its fullest or when it was finally managed. When governments could no longer prevent a debate over control of EU decision-making, we anticipate that the parliamentarians forcefully expressed demands for oversight mechanisms. Our explanation lets us thus expect that during the Great Recession Euro countries compensated their lack of policy autonomy by rhetorically expressing interest in more supervision over EU decision making, unless they were deeply in trouble and firmly dependent on supranational measures.

We provide evidence for our argument with cross-national data. We first analyze the adoption of oversight mechanisms for $25 \mathrm{EU}$ countries between 1957 and 2010. The historical evidence allows us to evaluate the difference in oversight adoption rates between policy-independent and EMU-dependent countries across several banking crises, which are the most representative financial shocks experienced in Europe in thepast decades (Laeven and Valencia 2012). We then test our hypotheses on the more recent Euro crisis, introducing new original data about parliamentary debates over EU oversight from three central Eurozone countries: France, Germany, and Italy. Together, the empirical results indicate that crises-ridden EMU outsiders are more likely to adopt stringent parliamentary oversight procedures if they are constrained through high debt. By contrast, crises in EMU states do not significantly influence the de facto adoption of oversight institutions. However, during the recent Eurozone crisis EMU parliaments expressed clear preferences for EU oversight in their parliamentary debates -but only when not deeply threatened by the crisis.

The findings contribute to extant EU research by suggesting how parliamentary scrutiny of EU affairs weakens due to the structural characteristics of the common currency union. Our research sheds new theoretical and empirical light on the political economy of EU parliamentary behavior (e.g., De Wilde and Raunio 2018; Hallerberg et al. 2018; Closa and Maatsch 2014), and the economic roots of the 'responsiveness vs. 
responsibility tension' EU national parliamentarians face (Laffan 2014). Furthermore, the results qualify the discussion of the losers' of EU integration and how these fight back during stressful times (Auel and Höing 2014; O’Brennan and Raunio 2007).

\section{Financial Shocks and Demand for Reforms in Suprana- tional Polities}

The Eurozone crisis reinvigorated the fear that the European Union has reached its nadir, falling victim to a final bout of what has been described as 'Eurosclerosis' (Giersch 1985). Skeptics have claimed that the EU's infrastructural inertia prevented the organization from introducing reforms that would enable it to effectively deal with financial shocks. Public intellectuals noted that the handling of the crisis undermined the principle of democratic delegation, pinpointing a trend towards technocratic, or even autocratic, decision making. Giddens (2012) stressed that, "those who have assumed the mantle of the saviors of the EU - Angela Merkel and Nicolas Sarkozy, together with 'technocrats' in Greece and Italy - are largely bypassing the decision-making agencies of the union." Similarly, Habermas (2011, 97) advanced the proposal of establishing a European transnational democracy in light of the "real possibility of a failure of the European project." Engaging with this discussion over bureaucratic hyper-efficiency and the so-called 'democratic deficit' (Moravcsik 2002; Majone 1998), some have argued that decisions in the EU are inherently problematic because they are made by government delegates who cannot base their position on a clear popular mandate (Føllesdal and Hix 2006). In concordance with this view, a crisis like the Great Recession should have created obstacles for parliamentary democracy across the crisisaffected countries.

However, looking closely at the political consequences of economic crises, a number of political economy scholars have suggested that the social costs of a recession can at times be so overpowering that they enable, rather than prevent, drastic reforms. Drazen and Grilli $(1993,598)$, for example, claim that "the extreme welfare loss that each agent suffers in a crisis dwarfs the loss he may associate with an unfavorable distribution of the burden of a major policy change" (see also Frankel 2005). According to this literature, sacking the allegedly responsible is at least a short-term response to economic crises. This may create incentives for democratic representatives - e.g. members of parliament (MPs) - to demand more control of the crisis management. Yet, how this responsiveness comes 
through in a complex interconnected polity like the European Union is still up to debate (Laffan 2014; Mair 2009).

The Eurozone crisis has in the meantime sparked a body of political economy literature that focuses on the political consequences and the adequacy of the supranational reform measures (Frieden and Walter 2017). A thread of this research concentrates on how the crisis has affected decision-making in the EU intergovernmental institutions (e.g. Finke and Bailer 2019; Wasserfallen et al. 2019). This article adds to this debate by seeking to uncover member states' responses to the crisis, and especially the requests of the national legislatures for more EU oversight, through political economy lenses. The EU literature has already largely established that the parliaments of the member states were not necessarily the helpless victims of the crisis as the alarmist early contributions had invoked. On the contrary, members of parliaments across Europe debated the causes and consequences of the crisis intensively (Maatsch 2017; Rose 2014). One of the core insights of this array of studies is the bewildering variation in the responses to the crisis, which manifests itself in debates about the EU as well as specific crisis management projects. Our research question is then, to what extent economic structures, and in particular the economic features of non-Euro and Euro countries, can help explaining this variation of implementations of-and demands for - EU oversight mechanisms.

Case studies provide some insights. Analyzing the debates in 11 Eurozone member states, Closa and Matsch (2014) show that Eurosceptic members of parliament were more likely to vote against the European Financial Stability Facility, describing the liabilities associated with the reform measure as a "crime" (p. 838) or depicting the alleged profiteers of the rescue package as "gangs of gamblers" (p. 839). Maatsch (2017) examines the parliamentary responses to the European Semester, the European Commission's newly gained competence to scrutinize member state budget plans, through a comparative case study of four EMU member states. According to her analysis, strong formal budgetary powers offer the leverage consenting parties need to challenge the supranational fiscal supervisor. Hallerberg et al. (2018) evaluate the parliamentary responses to the European Semester across all EU member states, identifying a cleavage between Euro insiders and outsiders. They attribute this surprising divergence to theinterest of politicians in EMU non-member states to signal to voters that they carefully consider the recommendations from Brussels.

The argument that we develop below follows a similar institutionalist view of domestic 
involvement in EU affairs (see also Auel and Christiansen 2015; Karlas 2012), but focusses more on than constraints of national members of parliament. ${ }^{3}$ In doing so, our article links the political economy literature on domestic constraints of cooperation with the comparative analyses of $\mathrm{EU}$ institutions. We see the $\mathrm{EU}$ as a predominantly intergovernmental body that makes decisions, on the one hand, through negotiations between the national delegates and, on the other hand, through power delegation to supranational agents such as the European Commission and the ECB. Consequently, our discussionbelow pulls together theinterrelated questions of how muchlibertytheEU should have for domestic parliaments to accept executive crisis management, and how muchscrutiny the intergovernmental decision making should receive for parliaments to represent grieving European publics.

\section{Integration and Delegation during Economic Setbacks}

Citizens in democracies experiencing the negative effects of financial turmoil should electorally threaten their political representatives unless their concerns are accounted for. Surely, citizens may not automatically punish the political elite if the source of the crisis is blurry or if the target of electoral punishment is diffused (Alesina et al. 2011). ${ }^{4}$ Still, European public opinion research suggests that voters expect their domestic institutions to act on their behalf and champion their interests, either by protecting their sovereign right to implement policy (De Vries 2018) or by engaging with EU economic policy coordination (Kuhn and Stoeckel 2014). We therefore assume that voters can prompt their political representatives to pull the strings of international institutions in basically two ways.

On the one hand, citizens can in the face of a crisis call their representatives to limit the government's influence on the economy. A large literature indicates that the natural substitutes of elected politicians during a financial downturn are technocrats. For example, at the spark of a crisis central banks may be given more autonomy to engage with markets and rebuild economic credibility (Bernhard et al. 2002). On the other hand, citizens can also demand more control of the political institutions that handle the

\footnotetext{
${ }^{3}$ In a sense, our angle departs from those that focus, for example, on the role of the executive (Auel and Höing 2014; Tarlea et al. 2019) and the varying flexibility of policy action across EU member states (De Wilde and Raunio 2018).

${ }^{4}$ This should also be true at the EU level, where supranational elections are still far from equivalent to their national counterparts.
} 
crisis - most commonly by empowering parliamentary assemblies. Both mechanisms could explain why crises often incite legislature to enact policy reforms, even in systems like the EU where economic and legislative decision-making is delegated.

Indeed, an alternation of these two types of mechanisms seems to have characterized the historical development of EU integration. Along these lines, Table 1 illustrates the cooccurrence of crises, supranational economic policy and arrangements for parliamentary delegation. The concatenation of events suggests that, often, delegation and fiscal constraints were designed to commit states to the EU project in the aftermath of economic crises. The collapse of the Bretton Woods regime in the 1970s confronted the European Community (the predecessor to the EU) with the first opportunity of reasserting its economic and political role. Under this pressure, the Malfatti Commission initiated discussions on the single market. Simultaneously, a treaty was signed authorizing direct elections to the European Assembly. The European Council started meeting in 1975 under similar circumstances. A significant enhancement of technocratic reforms and legislative power delegation occurred during the 1979 savings and loans crisis, despite the resistance of countries like Denmark and the UK (Giersch 1985). Similarly, the 1990s financial distress triggered varying reactions in the Union. The Black Wednesday pressured the UK into abandoning the European Exchange Rate Mechanism, but also prompted the core member states to intensify the plans for a monetary union. More recently, the 2008 crisis coincided with the enactment of the Lisbon Treaty, which strengthened the role of national parliaments and introduced new actors such as the President of the European Council. At the same time, especially under the pressure of some Eastern European countries, the crisis also escalated discussions on the mandate of the ECB and the European Stability Facility.

This historical overview highlightsthe important role that economic crises have played in the history of EU integration, although we do not imply that they had direct causal effects on EU supranational treaties, nor that new supranational economic arrangements directly whetted appetite for parliamentary delegation. Rather, these historical notes offer two observations about the varying influence of crises on EU oversight demands in national parliaments. First, the described events provide some indication that, at the outbreak of different crises, member states felt differently about the speed and depth of reforms in the Union - hence suggesting some important heterogeneity in preferences for control and oversight of the EU institutions. For example, a year following the start of the 2008 recession, Poland advanced the wish to re-launch the discussion on some areas of the Lisbon Treaty 
given concerns that recently achieved institutional consensus misrepresented the interests of Polish citizens. Similarly, the Dutch Prime Minister Balkenende demanded a greater rolefor national parliaments in the EU decision-making process (Finke et al. 2012: 171).

Second, the timeline illustrates that crises systematically triggered the demand for monetary policy innovations. Most recently, the EMU outsiders insisted that the envisioned Eurozone reforms would not affect them adversely, and that they deserved oversight of the process. Against this light, it may not be surprising that the 2012 European Council meeting concluded that the "process of completing EMU will build on the EU's institutional and legal framework. It will be open and transparent towards Member States not using the single currency". ${ }^{5}$

These historical anecdotes point to the distinction between EMU and non-EMU member states as a critical source of variation of EU oversight across European countries. We dedicate the rest of our theoretical discussion to this distinction. As other studies have argued (De Grauwe 2011; Genovese et al. 2016), policy makers inside and outside the EU monetary union possess divergent instruments to tackle a crisis. For non-EMU members, fiscal and monetary policy are the means governments and their delegates use to steer the economy. In the absence of a crisis, governments are generally capable of continuing to manage foreign creditors and domestic market expectations. By contrast, when a crisis erupts, a government needs to quickly stabilize the economy (Bernhard et al. 2002, 14). Increasing the power of the central bank, for example, is conducive to crisis mitigation, because the bank can stop the shrinking liquidity with changes in the money supply or, in drastic cases, exchange rate manipulations (Broz 2002). Consequently, the freedom of economic adjustment provided by free monetary policies may give the public in non-EMU countries stronger preferences for supranational control and parliamentary oversight.

By contrast, the policy portfolio of EMU member states differs dramatically. They do

\footnotetext{
${ }^{5}$ European Council, 2013, Rules for the organisation of the proceedings of the Euro Summits. https: //www.consilium.europa.eu/media/20377/qc3013400enc_web.pdf. A similar understanding of the crosssecting pressure of technocratic and delegation reforms in the EU and the varying role of economic structures can be drawn from data on national positions on the Euro and EU power delegation as measured via the Euromanifesto Project. The Appendix shows multidimensional scaling (MDS) plots of country-aggregate party platforms of past European Parliament elections. The graphs indicate that the countries at the 'periphery' of the MDS map have consistently been non-Euro countries, while that the position of at least one of the financially troubled countries in the Union (e.g. Portugal in the 1990s, Greece multiple times) was furthest from the position of monetarily sovereign countries (e.g. Denmark, Sweden, Czech Republic and Hungary).
} 
not possess the authority to single-handedly empower domestic technocrats (e.g. central bankers) in times of crisis, so they cannot engage the national money market nor have the ability to freely lower their exchange rate. At the domestic level, no quick policy fix increases liquidity in the time of a crisis. ${ }^{6}$ Furthermore, in EMU countries fiscal policy may not immediately synchronize with ECB policies. ${ }^{7}$ Building on these observations, in what follows we expand on the implications of EMU and non-EMU constraints for EU oversight, and spell out our testable hypotheses. ${ }^{8}$

\section{Financial Crises and National Parliamentary Oversight}

Our central argument is that financial crises can activate demands for parliamentary oversight subject to the level of member states' economic leeway. We hold that EU member state legislatures were systematically pressed to respond to popular concerns regarding crisis management (Auel, Eisele and Kinski 2018; Ruiz-Rufino and Alonso 2017), but that the extent to which they engaged in the monitoring of the EU bodies varies as a function of their constrained policy space. Along these lines, we explore when members of domestic parliaments urge their executives to increase EU oversight, and how their responses are directly dependent on countries' discretion in monetary and fiscal matters.

We assume that demanding supervision of an international institution and introducing mechanisms to oversee it invoke considerable costs because of the need to change the status quo. In the absence of economic stress, members of national

\footnotetext{
${ }^{6}$ Financial crises may also incentivize the creation of currency unions in the first place. In the EU, for example, the decision to create the common currency was also driven by the concern of recurrent financial shocks in Spain and Italy in the 1970s (Moravskic 2012).

${ }^{7}$ In EMU member states, expenditure adjustments were made following the Maastricht convergence criteria that allowed 'moderate' levels of debt up to 60 percent of GDP.

${ }^{8}$ While we refrain from concentrating on how economic constraints affect individual members of parliament or their parties, our intuition is that in a time of crisis European political parties experience on average a weakening capacity to bridge responsiveness between the electorate and the EU. In line with the mechanisms of "constrained choices" in the Eurozone delineated in Laffan (2014), we argue that the constraints of the monetary union create a gap between the electorates and members of parliament, forcing the latter to be very strategic about the timing of their demands for EU oversight. Similarly, we follow studies that claim that this declining capacityis consistent across most parties in a country affected bya crisis(Mair 2009; Wonka 2016).
} 
parliaments (MPs) have no reason tocall for the introductionor strengthening of EUoversight institutions as longastherearenoattempts to revise the EU treaties or (in case of ongoing accession) as long as the integration issue plays a large role during electoral campaigns.

After an external shock, however, domestic MPs face a stronger trade-off between responsibility to EU partners and responsiveness to the domestic electorate. The MPs' concern for responding to their electorates should grow, because voters expect their democratically elected representatives to make a case for their national interests (Armingeon and Baccaro 2012; De Vries 2018) and press for international reform (Kuhn and Stoeckel 2014). The public desire for domestic response should especially hold in the EU, which, since its inception, has constructed mechanisms to deal with different emergencies. However, these solutions are so complex that swift reactions to external shocks are often virtually impossible. We now discuss how responsiveness may vary as a function of a country's monetary and fiscal policy autonomy.

\section{Parliamentary Options under Flexible Currencies}

For countries with flexible monetary policy, a floating currency is a first-order instrument that can offset the pain of a financial crisis for two reasons. Firstly, letting a currency float can have a positive short-term economic effect. Floating currencies quickly boost net exports and strengthen cross-national investments, therefore raising income. Additionally, floating currencies have a meaningful impact on political stability, which is crucial in periods of economic stress (Broz 2002). In these countries, the responsibility for the crisis management is fully delegated to the executive or diffused to other domestic institutional actors, such as central bankers, which have the tools to take action on the national currency and calming the markets (Cukierman 1992).

Due to the quick effects of floating currencies, we expect monetary action to mitigate public concerns with crisis management, at least in the short run and independently of what supranational institutions do. In other words, we anticipate that people in nonmember states who observe domestic institutions addressing their financial crisis have no pressing rationale for asking their parliamentarians to further control EU decision-making. So, while focusing on the inward politics of crisis management, national parliaments in countries with independent monetary policy would be less likely to demand more EU surveillance at times of economic vulnerability. 
Hla: At theoccurrence of a financial crisis, national parliaments of non-EMU member states are less likely to adopt stronger EU oversight institutions, ceteris paribus.

That said, governments ultimately depend on the state of the real economy to fully appease their national voters. For states with an autonomous monetary policy, the way currency devaluation works most effectively is in combination with government spending. However, in the EU, fiscal policy - the "crown jewel" competence of parliaments (Puntscher Riekmann and Wydra 2013) - is hardly a free instrument. Even monetarily independent countries need to match debt sustainability standards stemming from EU fiscal regulation (Alesina and Giavazzi 2013). Depending on the level of debt at the time of crisis, a given EU country may differently depend on the rules governing the European economy.

We thus also expect that the national level of debt at the onset of a financial crisis may mediate the demand by MPs for EU oversight. Evidently, a country that stays outside of any monetary arrangements and that preserves a low level of debt easily has more leeway for pursuing counter-cyclical spending policies during a crisis. Its government does not face sever constraints that would prevent it from using fiscal stimuli to appease its electorate. Importantly, fiscal action may be calibrated more easily, and policy makers depend less on what other EU states do to kick-start their economy.

Now contrast this with countries with higher debt. Historically, all EU countries were made fiscally liable by nominating their debt in the common currency. ${ }^{9}$ The EU rules of nominal debt convergence make independent monetary policy potentially less effective in case of tight debt levels, as deviation from the books is made harder by the supranational institution. Furthermore, when debt levels are high, it is crucial that the weakened currency is ever more effective at capturing foreign capital (Bordo and Schwartz 1997). However, if the market economy of EU neighboring countries does not adequately improve, exports and incoming investments may not increase at the desired rate. Consequently, in monetarily independent states with high debt levels people are more

\footnotetext{
${ }^{9}$ This was true of the Treaty of Brussels as the 2012 European Fiscal Compact.
} 
sensitive to the supra-imposed EU commitments and the EU economic policy as a whole. Hence, we expect that in non-member crisis countries, a government's fiscal involvement would increase a parliament's demand for controls on EU decision-making.

$H 1 b$ : At the occurrence of a financial crisis, national parliaments of non-EMU member states are more likely to adopt stronger EU oversight institutions as their national debt increases.

\section{Economic Restrictions and National Parliamentary Debates in the Eurozone}

We now turn to discuss the implications of institutional constraints at the time of a crisis for EMU countries, focusing specifically on the recent 2008 crisis. States inside the EMU can neither rely on monetary tools nor access easily fiscal options to keep the crisis at bay. However, this does not preclude that people in these countries have similar crisis fears as those in non-member states. In fact, the very constraints of the single currency may make grievances even stronger, as shown by some of the massive protests in the Eurozone at the beginning of the Global Recession (Genovese et al. 2016). Similar to the dynamics unfolding in states with autonomy in monetary matters, we assume that the 2008 crisis created pressures for parliaments to oversee the EU more (Auel and Höing 2014). However, parliaments in the EMU had to choose whether to be responsible to the EMU commitments (Ruiz-Rufino and Alonso 2017) or to respond to the "interests of the many" to dampen the anticipated electoral punishment (Puntscher Riekmann and Wydra 2013). We expect that such pressures also exists for MPs in parliaments of EMU member states.

On the one hand, we expect that at the onset of the Euro crisis domestic parliaments were able to overall refrain from instituting more de facto EU oversight institutions for two reasons. First, EMU countries have had more mixed preferences about EU oversight than countries outside the Eurozone due to their 'shared fate'. While (like non-EMU states) Eurozone members' parliaments might have had the incentive to decrease pressure on their executives and let them operate with lower levels of accountability at the outbreak of a crisis, they were also compelled by voters to pay more attention to EU institutional affairs due to the high-risk spillover effects of a common crisis (Frieden and Walter 2017). Second, public grievance in Euro countries during the crisis was effectively diffused by supranational actions - for 
example, the real and symbolic reactions of the ECB (Genovese et al. 2016). Evidently, EMU member states also differ substantially with regard to the extent to which they are able to shape a crisis response as well as economic governance reforms according to their fiscal interests. But while fiscal flexibility and debt levels may have mattered in the debates within Euro countries (as we describe at the end of this section), we believe that, on average, the Eurozone member parliaments preferred for the EU to operate at its discretion. We then expect that the effect of the crisis on the de facto adoption of parliamentary oversight institutions in Euro countries should be undistinguishable from zero. In other words, Eurozone membership did not moderate the effect of the crisis on oversight.

On the other hand, these considerations do not imply that EMU states did not show support for EU oversight in other ways. Ultimately, we hold that during the 2008 crisis "smoke came with fire": the management of the crisis could not be fully diffused, and domestic parliaments had to give in to the public demand for parliamentary supervision of the EU, at least in part, if only because of the concerns with political consequences of not doing so (Hooghe and Marks 2009). We suspect that this compromise is observable in parliamentary debates in that at minimum parliaments had to place the issue of EU oversight in the discussion agenda (Puntscher Riekmann and Wydra 2013; Rauh and de Wilde 2018).

We nevertheless posit that members of parliaments approached these debates strategically, following the development of the crisis. At the heightened moments of the crisis, we expect parliamentarians to stay out of the spotlight and refrain from debating EU oversight. After all, reproaching the supranational institutions or other member at the most difficult times may have direct negative consequences for the Eurozone, and Euro parliaments want first and foremost for the supranational institutions to fixthe troubled common market. We expect that parliaments in Euro countries with high debt were especially less predisposed to provide a forum to discuss oversight given their dependence on the EU's unconditional authority during the crisis. Vice versa, Euro countries with enough fiscal policy room felt more liberty to legitimize their concerns over the direction and magnitude of EU decision-making during the crisis. However, across the Euro countries, we expect that - when given the opportunity to debate oversight of EU institutions - most parliamentarians would have catered to the median voters' short-lived concerns (Schraff and Schimmelfennig 2019), and tilted towards further supervising the EU. 
$H 2 a$ : At the climax of the Euro crisis, national parliaments of Eurozone member states were less likely to debate EU oversight, especially if highly fiscally indebted.

$H 2 b$ : If at the climax of the Euro crisis national parliaments of Eurozone member states discussed EU oversight, then they were more likely to demand more oversight, especially if highly fiscally indebted.

We test our hypotheses in two steps. First, we evaluate the meaningfulness of $\mathrm{H} 1$ for crises up to the Global Recession with a EU-wide historical analysis of oversight institution adoptions. Then, we test $\mathrm{H} 2$ with a more current, fine-grained analysis of the frequency and content of EU oversight debates in the French, German and Italian parliaments.

\section{Historical Cross-National Analysis: Crises, Oversight Institutions and Policy Constraints}

Our first analysis investigates the differences between parliamentary adoption of oversight institutions across EMU and non-EMU countries by estimating the effect of monetary and fiscal constraints at the onset of a crisis. Here we focus on EU countries since 1957 with yearly data.

\section{Data}

To test the effects of economic crises on domestic parliaments' adoption of EU oversight institutions, we collected indicators for EU members between 1950 (the year after the statute of the Council of Europe entered into force, or whichever first date afterwards for which a country's macroeconomic data is most up to date) and 2010 (the end year of available data on EU oversight reforms). The dataset comprehends 25 states, i.e. all EU countries with the exception of Luxembourg and Malta due to data limitations. ${ }^{10}$

Because we are interested in explaining how legislatures press for more accountability at the EU level, our outcome variable needs to proxy national parliaments' formal requests

\footnotetext{
${ }^{10}$ The states under analysis are Austria, Belgium, Bulgaria, Cyprus, Czech Republic, Denmark, Estonia, Finland, France, Germany, Greece, Hungary, Ireland, Italy, Latvia, Lithuania, Netherlands, Poland, Portugal, Romania, Slovenia, Slovakia, Spain, Sweden, and the UK. Our data frame starts in 1950 based on the availability of macroeconomic data, so for Austria, Belgium, Denmark, Finland, France, Germany, Greece, Ireland, Italy, Netherlands, Portugal, Spain, Sweden, and the UK our series starts in the 1950s. For Cyprus and Romania it starts in 1961. For the rest, it starts in 1970. This implies that many countries were included in the analysis before they formally joined the EU (even if several were linked with the EU via an association agreement). In these cases, oversight institutions are assumed to not exist and take the value of zero. Coding them instead as missing, however, does not significantly change the qualitative results of our analysis.
} 
and explicit mandates to control the EU decision-making process. The most comprehensive dataset for our purposes is described in Winzen (2012). This data includes rules codified in formal documents, constitutions, legislation, and ministerial procedures across European countries since 1957. It also codifies all institutional bodies that parliaments have adopted (or eliminated) in order to counter the political constraints that the EU allegedly creates. Our main outcome variable, Oversight Institutions, comes from Winzen (2012), who coded parliamentary oversight institutions introduced to better control EU affairs. While Winzen's original data reports the frequency of disaggregated instruments, for example the memoranda to the European Affairs Committees, we use his aggregated oversight institutions index and multiplied it to 100 so that it goes from o to 175 . For the main analyses, we standardized the index to create an interval ranging from $o$ to 100 to ease the interpretation for the statistical models. ${ }^{11}$ According to the compound measure, EU oversight changed 72 times (this is more than the 54 parliamentary reform changes reported in Winzen, although he accounts only for a subset of the indicators included to form his final index). As Winzen (2012) points out, EU oversight has overall increased over time, although not systematically and at different paces across the member states. ${ }^{12}$

Based on our theory, a critical driver of parliamentary institutions to oversee the EU is the occurrence of a financial crisis. Here we focus specifically on banking crises, as these are considered the most relevant financial shocks in Europe in the past decades, and also mattered prominently for stability in the context of the Great Recession. ${ }^{13}$ We rely on the data compiled by Laeven and Valencia (2012), who define banking crises as financial distress in the banking system, significant bank runs, losses in the banking system, and/or bank liquidations followed by policy intervention measures in response to significant losses in the banking sector. Laeven and Valencia report data from the 1970s; other sources (Giersch 1985; Hsu 2013) report the lack of crises during the inter-crisis (Bretton Wood) period, and we rely on these to start the series from the $1950 \mathrm{Os} .{ }^{14} \mathrm{In}$ sum,

\footnotetext{
${ }^{11}$ Winzen (2012) describes the weighting of the different 'dimensions' that he identifies across all the procedures and rules. Substantively, the index has a minimum of zero and a maximum of 3.

${ }^{12} \mathrm{We}$ illustrate the complete data captured by the Winzen variable in the Appendix.

${ }^{13}$ We prefer crises in the banking sectors over currency depreciations because EU discussions on the unitary peg have to some extent anticipated weak currency moments. Moreover, commercial banks behave as independent international agents, so banking crises represent a more strictly exogenous type of crises.

${ }^{14}$ According to Laeven and Valencia (2012), a banking crisis needs to be 'systemic' to enter their dataset. This means that issues of liquidity from subsidiaries of a multinational bank or issues specific to domestic financial regulations do not constitute an observation, at least not directly. We decided to conservatively treat France, Slovenia and Sweden as "non-obvious" crisis cases because of the information reported in Laeven and Valencia (Table 3; Table A2). That said, further analyses that include these cases show results consistent with our findings.
} 
Our variable Banking Crisis takes the value of 1 if a country experienced financial distress, and $o$ otherwise.

Following our theory, the outbreak of a financial crisis would have direct implications for EU oversight institutions especially in non-EMU member states, because parliaments in monetarily independent countries should be less inclined to increase - and may even potentially decrease - EU oversight while dealing with the internal politics of crisis management. However, we also contend that a country's liberty to address the crisis by fiscal means should explain the parliamentary adoption of EU oversight institutions. Consequently, we operationalize a measure of Debt to GDP for our conditional analyses. To construct this variable, we rely on public debt data from Abbas et al. (2011), which we updated for the recent years with OECD debt to GDP ratios. The debt measure ranges from 1 to 216.9, with highest values reached in the 1950s in the UK but also in the 1990s in Bulgaria.

The background summary of our data provides initial anecdotal support for our theoretical conjecture. A range of countries in our dataset underwent financial crises along the 60 observed years, and not only with the 2008 global recession. Some of them undertook significant monetary actions during the identified crises. Notably, among the countries that at the time had independent monetary policies, all increased central bank independence (as measured via indicators of Bodea and Hicks, 2015) right after their crises. This is, for example, the case of Spain in 1975 and Sweden in 1993. By contrast, EMU member states lost their reform capacity with their entry into the Eurozone, yet the 2008 crisis did not have impacts of the level of independence of the ECB. As our theory suggests, decision makers in independent monetary systems seem to leverage monetary policy to reinstate trust in investors during a crisis, while the same does not hold for countries in the monetary union.

But more relevant to our analysis is the distribution of parliamentary EU oversight institutions. As already reported by others, the adoption of EU oversight institutions between 1950 and 2010 also varies significantly across European states. We observe substantive changes to EU oversight institutions at the onset of banking crises, but not all in the same directions. Among EMU countries, the Winzen index suggests that national parliaments tightened control as states were forced to give up considerable sovereignty in the run-up to the Euro; however, no further visible changes to oversight institutions are observable at first hand in either troubled or 'safer' EMU countries in 2008-2010. By contrast, non-EMU countries suchas BulgariaandPoland introduced more EU oversight controls in the late 2000s, in the 
midst of the global financial crisis (see Appendix for anoverview of the Winzen data).

We visualize some anecdotal patterns for a number of non-EMU and EMU countries in Figure 1. The plots show that, before the Global Recession (and thus, the Euro crisis), EMU countries like France and Greece similarly strengthened their national oversight institutions, possibly as a reaction of the Maastricht Treaty. As the global crisis occurred, demand for parliamentary scrutiny in France increased, though marginally, while indebted Greece did not advance any reform. Similarly, while indebted Belgium refrained legislative scrutiny in 2008, the Dutch parliament increased oversight rights, but these reactions were still contained due - as we argued - to the constraints imposed by the EMU. Starker differences instead emerge when comparing two newer EU members such as Bulgaria (nonEMU) and Cyprus (EMU). Surely the increase in oversight institutions in these countries was linked to the time at which these countries adopted EU policies, as well as other factors such as their distinct political structures (for example, Cyprus is the only presidential system in the EU). But in accordance with our predictions, Bulgaria - which was not directly subject to the crisis - adopted significantly more controls once the Great Recession broke out. ${ }^{15}$ By contrast, Cyprus - despite a shrinking economy and a pressed banking system in 2010 - demanded no further controls with the crisis outbreak. Keeping with the mentioned caveats, these anecdotes are in line with the possibility that parliaments in EMU and non-EMU countries responded differently in terms of adopting mechanisms for EU oversight. Weexplore the validity of this hypothesis with the following analysis.

\section{Estimation Strategy}

Our data has a longitudinal format. However, testing for stationarity we find that some of our central independent variables - in particular Debt to GDP - contain unit roots, which make the estimated coefficients of time-series models inefficient and potentially spurious. To overcome this issue, we rely on Error Correction Models (ECMs), which are models for both stationary and non-stationary time series in cross-national panels. An ECM specification imposes a lagged dependent variable that may be correlated with the timeinvariant component of the error term and precludes the estimation of unit fixed effects. Nevertheless, it has been shown that the ECM provides accurate results in dynamic processes. It also appears particularly useful for our study as it estimates the "speed" at which the

\footnotetext{
${ }^{15}$ For example, in 2012 the Bulgarian Committee on European Affairs and Oversight of the European Funds prepared a work program that included parliamentary observation and control of European financial instruments, humanitarian aid and crisis response. This was not a response to a national crisis but to the overall EU crisis.
} 
outcome variable returns to equilibrium after long- and short-run changes in an independent variable. Last but not least, model interpretation can be simplified by calculating long-run multipliers.

Equation 1 summarizes our linear ECM estimation:

$\Delta$ OversightInstitutions $_{i t}=\alpha_{0}+\alpha_{1}$ OversightInstitutions $_{i t-1}+\beta_{1} \Delta$ Crisis $_{i t}+\beta_{2}$ Crisis $_{i t-1}+\beta_{3} \Delta$ Debt $_{i t}$

$+\beta_{4}$ Debt $_{i t-1}+\beta_{5} \Delta$ Crisis $_{i t}{ }^{*} \Delta$ Debt $_{i t}+\beta_{6}$ Crisis $_{i t-1}{ }^{*}$ Debt $_{i t-1}+\beta_{7} \Delta \mathbf{X}_{i t}+\beta_{8} \mathbf{X}_{i t-1}+u_{i t}$

(Eq. 1)

In our notation, for each country $i$ at year $t$, change in Oversight Institutions is the outcome variable. The parameter $\alpha_{0}$ denotes the unknown intercept for each country $i$, whereas $u$ is the error term. The equation includes the lagged version of Oversight Institutions, as well as the level and change in Banking Crisis, which represents the major source of financial shock explored in this section of the paper. The level and change of Debt to GDP reflect the long- and short-run constraints to fiscal expansion. We are mainly interested in the estimated unconditional coefficients of Banking Crisis as well as the estimated interaction Banking Crisis*Debt to GDP. As per our theoretical discussion, we expect substantive differences in the results for monetarily independent countries vis-à-vis Eurozone countries. Wepredict that exogenous shocks to the banking sector systematically depress the adoption of EU oversight institutions in non-EMU states, yielding negative $\beta_{1}$ and $\beta_{2}$. We also anticipate that this effect may be mediated by fiscal capabilities in these countries, and that high debt may actually revert parliaments' interest in overseeing EU decision-making during a crisis, shown by positive $\beta_{5}$ and $\beta_{6}$. Vice versa and following our theoretical argument, the hands of Eurozone countries are more tied, and their parliaments are too dependent on central actions of EU institutions (e.g. the ECB) to quickly pass EU scrutinizing legislation in the aftermath of a crisis. Thus, we expect less consistent effects among EMU countries.

Due to the inferentiallimitations of observational analysis, weadditionally control for a conservative number of alternative explanations for EU oversight institutions. An increasing Inflation Rate may trigger reforms as rising price levels decrease voters' trust in the political elites. So, wecollected thehistoricalyearly rateofinflation based on theconsumerpriceindex from the EU Statistical Offices, compiled by Inflation in Europe. Additionally, Government Ideology - as in, the party orientation of the executive - may foreshadow the likelihood of parliamentary reforms in general, and on the EU in particular (Senniger 2019). On this front, we use the CPDS data that takes values from 1 (left-wing) to 5 (right-wing), and that goes from 1960 onwards (Armingeon et al., 2011). We prefer this parsimonious measure 
given the nature of the ECM estimation, which - by capturing both levels and changes of political ideology, automatically calculates the volatility versus stability of power shares of parties in the system. That said, in additional analyses we also employ measures of public and party Euroscepticism and internal parliamentary dissent that the literature also uses in analyses of European legislatives politics (Karlas 2012; Spoon and Williams 2017), as well as the type of political system (i.e. presidential or not) in place. We also discuss the role of EU treaties that may influence parliamentary oversight reforms in additional checks.

Once again, our argument specifies the impact of different monetarysystems. To account for this important variation, we split the samples by sovereign currency countries and monetary union countries. ${ }^{16}$ Sovereign currency countries indicate all countries that had independent monetary policy at each year $t$, including (for the more recent years) the longterm EU members that actively opted out of the Euro. Monetary union countries refer to countries in the Eurozone. ${ }^{17}$

\section{Results}

We start by presenting regression results of Oversight Institutions for non-EMU countries in Table 2. Model 1 estimates the unconditional effects of the crisis measures on the oversight institutions index. We find that, while Debt to GDP has virtually zero partial effects, the onset of a Banking Crisis significantly decreases the likelihood of EU oversight institutions being adopted in a monetarily independent EU state. The effect is important for both the short-and long-run estimates of the Banking Crisis variable, and the magnitude is substantial (circa 7 percent change in the $0-100$ scale). This finding is in line with our expectation that, in crisis countries where monetary policy is nationally controlled, parliaments do not have immediate pressure to push for mechanisms to oversee EU decision-making.

In order to validate if there are differential effects of a crisis according to the national level of fiscal leeway, in Model 2 we estimate the interaction between Banking Crisis and

\footnotetext{
${ }^{16}$ Countries are coded as EMU member states in the year they agree to the currency unification, which varies and does not necessarily correspond to the official 1999 introduction of the Euro. Austria, Belgium, Finland, France, Germany, Ireland, Italy, Netherlands, Portugal and Spain agreed to currency unification and Euro peg in 1995 (the year that marks EMU integration after the ratification of the Maastricht Treaty). Greece became EMU member in 1998. Cyprus entered in 2004, followed by Slovenia in 2006, Slovakia in 2008, and Estonia in 2010. It is reinsuring that the results for the EMU countries are similar if we use 1993 (the signing year of the Maastricht Treaty) or 1999 (the establishing year of the ECB).

${ }^{17}$ Evidently, the observed crises in this latter group of countries refer mostly to the 2008 crisis. However, this series also include separate crises, such as the Finnish banking crisis.
} 
Debt to GDP. Conditional on a sudden increase in debt $(\delta)$, we find that EU countries hit by a banking crisis revert to more parliamentary oversight institutions. The short-run effect is substantive, and it is also meaningful for the overall equilibrium effect of Debt to GDP as denoted by the statistically significant and positive long-run multiplier of the interaction. The results is also in accordance with our hypothesis that countries that can move monetary policy to manage their crisis will only care about overseeing EU decision-making if their fiscal constraints make them more dependent on the EU.

In the separate regressions reported in Table 2, we run our models on the subsample of EMU states. In Model 3 we find that Banking Crisis - which, for the purpose of this model, is the 2008 recession - has insignificant results on the adoption of oversight institutions, as does the Debt to GDP variable. The interaction reported in Model 4 is also inconsequential: we find that parliaments in EMU states, regardless of their fiscal constraints, are not more likely to adopt institutions to control EU decision-making in the aftermath of a crisis. Again, this sheds light on the general mechanism envisioned by our theory. While a crisis and fiscal indebtedness may have caused deep economic and political concerns among EMU publics, the data indicates that Euro parliaments did not channel the public pressure into more supervisory action on the EU - due, as we argued, to economic policy constraints.

The interpretation of these results is robust to additional analyses reported in the Appendix. Weexplored how thefindings mirror the logic of increasing capability of technocrats - and specifically national central bankers - at the time of crisis. We therefore ran regressions of Central Bank Independent (CBI) that follow the same specifications of the main models run on Oversight Institutions. ${ }^{18}$ In the 1993-1998 period leading up to the introduction of the Euro, EMU countries (including Germany) made their central banks more independent in order to converge with the standards anticipated for the ECB. From 1999 onwards, all EMU countries are assigned a CBI score of 86 percent. $^{19}$

We find that a banking crisis has a positive and significant impact on the change in autonomy of central banks in countries with independent currencies. Substantively, a crisis

\footnotetext{
${ }^{18}$ To construct the CBI variable, for the years between 1950 and 1973 we leverage the classic Cukierman index. For 1973 to 2010, we use data from Bodea and Hicks (2015). The indicator goes from o for 'perfect dependence' to 100 for 'perfect independence.'

${ }^{19}$ Countries that adopted a peg to the Euro in 1999-2000 were Austria, Belgium, Finland, France, Germany, Ireland, Italy, Netherlands, Portugal and Spain. Greece joined in 2001, Slovenia in 2007, Cyprus in 2008, and Slovakia in 2009. Denmark adopted the European Exchange Rate Mechanism but not the currency. Bulgaria, Czech Republic, Hungary, Poland, Romania, Sweden and the UK are not part of the EMU.
} 
produces roughly eight point changes in CBI, holding all else constant. We also find that the interaction between Banking Crisis and Debt to GDP has the expected direction, in that a deepening crisis compound with an involved fiscal policy increases CBI in the shortrun. ${ }^{20}$ The estimations for EMU countries are instead small and statistically insignificant, consistent with our argument of institutional constraints and policy impossibilities.

Our results are also robust to several other sensitivity tests. One concern might be that our comparison between non-EMU and EMU states may be driven by selectiveattributes of the non-EMU countries that do not match the Euro countries. In alternative models we test the sensitivity of our results to other sample definitions, specifically with regards to the non-EMU countries. Weseparately focus on states that have always been independent in the 60 years covered by our dataset, states that did not belong to the EU until the large Eastern Enlargement of 2004, and all monetarily independent states observed only between 1995 and 2010 (as our EMU countries). We find that crises still have a negative and statistically significant impact on the index of EU oversight institutions across all alternative non-EMU groups, but as expected the effect switches to positive as debt increases.

Weseparately exploretherole of supranational treaty revisions as independenttriggers for parliamentary oversight reforms, for some of the crisis years in our dataset also include the entering into force of EU treaties. In additional analyses we then controlled whether an observation occurred before or after the ratification of the Treaty of Rome (1957), the Single European Act (1986) as well as the Treaties of Maastricht (1992), Amsterdam (1997), Nice (2001), and Lisbon (2007). The results in the Appendix indicate that parliamentary reforms can indeed be in part explained with treaty enforcement, especially with respect to Maastricht, Nice and Lisbon. That said, the substantive interpretation of our previous analysis remained unvaried, as the focal variables of this paper retain the same effects reported in the main analyses.

Furthermore, we recalculate our regressions including an additional variable for political systems, to test whether parliaments in different systems of government have adopted EU oversight institutions in systematically different ways. Wecontrol whether a system is purely parliamentary, semi-presidential or fully presidential. The results in the Appendix indicate that fully presidential systems (e.g. Cyprus) are less likely to advance oversight institutions

\footnotetext{
${ }^{20}$ These results fit the case of Portugal in the 1970s, when economic hardship led to a crawling peg to the Sterling, which eventually decreased the central bank autonomy.
} 
compared to the other systems, but semi-presidential systems have no significance variation over purely parliamentary systems. More importantly, the unconditional and conditional effects of crises and debt on EU oversight institutions remain unchanged.

We also study whether our main findings are sensitive to indicators of public and party Euroscepticism that the literature prefers to use in analyses of European politics. Specifically, for publicEuroscepticism weuseESS data, whilefor party Euroscepticismand party division on EU integration we use indicators from Spoon and Williams (2017), which are based on the European Election Studies and the Chapel Hill Expert Survey, respectively (similar indicators are used by Karlas, 2012). There are several caveats with these measures, for example that party Euroscepticism is measured only at points in which party manifestos were issued (so during some form of election). Furthermore, the variables are not complete for all countries in our sample, to the extent that we only can run them on a subset ofour EMU countries. Wefind that banking crises in high indebted countries have some influence on oversight institutions, however the long run effects contradict the short run effect, and the equilibrium is null (as shown by the negative but insignificant long-run multiplier). Substantively, our theoretical intuition is not proven wrong by the operationalization of these additional political indicators. ${ }^{21}$

\section{The Euro crisis and Parliamentary Debates on EU Oversight: Evidence from the Eurozone}

The historical evidence presented so far indicates that monetary regimes are critical explanations of EU countries' parliamentary power delegation, and that the Euro made a significant difference on how states react to the EU after economic emergencies. In this section, we explore the timing and nature of Euro crisis debates to test our hypothesis about parliamentary concessions to the EU oversight discussion in three Eurozone parliaments.

\section{Data}

We collected new original data on national discussions over EU oversight. For our purposes, we used the scripts of national plenary parliamentary debates (Auel and Raunio

\footnotetext{
${ }^{21}$ In the Appendix we also show that our models adequately control for spillovers between states and are not sensitive to Winzen's alternate indicators of oversight.
} 
2014; see also Rauh and de Wilde 2018). Because our research here investigates national sentiments over the way the EU handled the financial crisis, we focused exclusively on parliamentary debates dealing with 'economic stability', 'crisis management' and 'EU institutions'. We study these debates between September 2007 and April 2014, which we believe to be the core crisis years. In terms of country selection, we focus on three major Euro parliamentary democracies: Germany, France and Italy. These are historical EU members, but have different structural characteristics - especially in regards to debt and economic policy making - that we exploit to test our argument. ${ }^{22}$

We first tried to identify the most relevant debates. We preferred manual searches rather than more automatized techniques like scraping, because our analysis requires information about precise debates rather than general mentions (Rauh and de Wilde 2018). We searched through the official data archives of the Bundestag (Germany), the Assemblée Nationale (France), and the Camera dei Deputati (Italy). ${ }^{23}$ We found 154 debates for Germany, 133 for France, and 97 for Italy, for a sum of 390 debates over the period of 80 months. ${ }^{24}$ These numbers are relevant if one considers, for example, that the German Bundestag archives between 2007 and 2014 years reports a grand total of 542 protocols. Clearly, national parliamentarians spent a significant amount of time during these years debating the capacity of European institutions and the checking role of legislatures during the crisis (circa one in four debates for France and Germany, and one in five for Italy).

Our hypothesis is that debates over EU oversight in Euro countries were less likely at the climax of the crisis, when domesticinstitutions needed the supranationalinstitutions the most. However, we hold that some debates had to occur for all purposes, so when they talked

${ }^{22} \mathrm{We}$ are aware three countries are not fully representative of the Eurozone, and that the country selection limits the inferential capacity of our analyses. That said, we think these countries' parliamentary debates are reasonably comparable, as per other scholarly work (e.g. Maatsch 2017). We also believe that the case of Germany, however 'special' in the context of EU politics, is "an important case to study politicisation during the Euro crisis due to the country's current economic and financial weight and its strong political influence on the political dynamics and the course taken by the EU during the Euro crisis" (Wonka 2016:127).

${ }^{23}$ We downloaded the debates from the following pages: https://www.bundestag. de/service/suche for the Bundestag; http://archives.assemblee-nationale.fr/ for the Assemblée Nationale; and http: // leg. camera. it/ for the Camera dei Deputati. Welooked for texts that included combinations of following key words: "financial crisis", "European Union", "European Commission", "European Central Bank", and "European policy". This means that debates mentioning the EU, the Commission and European policy but not crisis were selected as well, but were screened for relevance (and given the temporal window taken in consideration, most often they did involve a discussion on the crisis). In the Appendix, we report the full list of the identified debates per each country. Research assistants looked at a random selection of the debates when deciding their ultimate relevance for our study.

24 It needs to be noted that each protocol in Germany covers a whole plenary meeting, each usually covering several very different agenda topics. This is an important caveat that may have consequences for the comparability with France and Italy. We also realize that the parliamentary systems of the three countries allow for slightly different roles to each lower chambers. Still, we focus on lower parliamentary houses only, following Rauh \& De Wilde (2018). 
about the handling of the crisis, national parliamentarians strongly expressed interest in more EU scrutiny. Against this background, we start by descriptively exploring the Number of Parliamentary Debates variable against these expectations. Figure 2 reports the temporary patterns of the debates in our dataset, and contrasts these with two indicators of the recent financial crisis: the Greek long-run bond yield and the European Central Bank deposit rate. The bottom graph reproduces the parliamentary debates by country, with in the background each national debt to GDP ratio. The illustrated numbers are in absolute terms, but the patterns are very similar if we take relative frequencies of the Euro crisis debates over all debates (correlation of 0.765 ; see the Appendix).

Across all countries, topical debates on the Euro crisis and EU institutions pick up towards the end of 2008, after the collapse of the Lehman Brothers. The debates continue through 2011, but hardly escalate. While they shortly increase in early 2010 when the first negotiations between Greece and the EU began (we count twelve debates in the three countries in May 2010), they quickly revert as soon as the crisis deepens, as demonstrated by the rising debt levels in the subplots. The number of debates goes up again during the 2011 "stress test", which artificially devised a financial scenario where banks stopped lending and households required income support. But again, debates were relatively contained up until the second half of 2012, during which EU governments discussed the Cyprus bailout and debt restructuring for Greece (only in France multiple debates are recorded in the late 2012). In 2013, when the Treaty on Stability, Coordination and Governance (the "Fiscal Compact") was enforced, more debates are observed.

These patterns offer two considerations that are relevant to our theory. First, the plots suggest that the frequency of the debates on EU oversight changes across time and is not driven by one specific core Eurozone country. Second, it seems that debates varied as a function of two measures that the political economy literature on the Euro crisis has shown to be relevant to measure the seriousness of the crisis, namely the variation in GreekGermany bond spread and the market actions of the ECB (Genovese et al. 2016; Frieden and Walter 2017). These two monetary aspects are tied to national debt levels in that this constitutes the only policy national governments can use to compensate for the national sacrifices of the crisis, at least partially. Importantly, the debates in Italy (the most vulnerable country in our sample) seem to have a negative relation with the country's debt, while debates in Germany (a stronger crisis country with the lower debt) were the densest. 
After collecting the debates, we proceeded on defining a dictionary that wethen applied to each of the identified texts to capture the sentiments for and against more EU scrutiny by the national parliament. Our dictionary included 10 "pro scrutiny" words and 10 "antiscrutiny" words, which we conceptualize as indicators of 'demand for EU oversight' and 'refrain from EU oversight', respectively. The two sets of words were considered mutually exclusive. For example, for pro-scrutiny, we identified the words "surveillance mechanisms", "parliamentary mandate", "oversight", "national safeguards" and "parliamentary vigilance", among others. Vice versa, the anti-scrutiny words included "supranational governance", "European mandate", "supranational competence", and "EU autonomy", among others. ${ }^{25}$ In addition to these words, we also recorded the frequency of terms that we believe to be separately connected to feelings of Europeism or Euroscepticism. So, in a separate count, wealso kept track of the number of times parliamentarians referred to words such as "integration" and "solidarity" versus words such as "sceptical" and "forced harmonization".

Upon translating the dictionary and qualitatively validating the meaning of the key words in a random subsample of the texts, we performed the coding of the frequencies that each word hit for each debate. ${ }^{26}$ Figure 3 reports the raw counts for selected key words (aggregated by country). On average, the "pro-scrutiny" words are repeated more often than the "anti-scrutiny" words, as evinced by the x-scale in the plot. This makes sense in light of the fact that we are observing speeches in national parliaments, which by definition are committed to preserve sovereignty from international institutions. What is perhaps more interesting is the variation of the raw counts across the three countries. Germany and France parliamentarians refer to "scrutiny" and "oversight" more often than Italy's deputies, who only significantly refer to "national accountability" '. As for what we consider anti-scrutiny words, Germans alone mention "EU centralization" and "EU autonomy" ' more than twice. These suggestive patterns indicate substantive variability across these three structurally different countries.

In addition, one may say that the Net Support for Scrutiny - corresponding to the

\footnotetext{
${ }^{25}$ See Appendix for the full list of words in the dictionary. Note however that our results are not sensitive to any specific term (see below discussion on German debates).

${ }^{26}$ The coding was supervised: three research assistants read through the paragraphs where the selected words appeared, to make sure they had the meaning set by the authors in their codebook. We did worry about coding observations that were unrepresentative or unconnected to the goal of the dictionary, so we interpreted the words in context. We also had cross-checks and allowed for occasional deliberation among the coders when in doubt. Evidently, these strategies are not a perfect guarantee against errors and false positives, as suggested by Rauh (2018). We come back to this in the discussion of robustness below.
} 
relative number of the logged sum of "pro-scrutiny" words over the logged sum of "antiscrutiny" words for each month-country - seems to vary according to the countries' experience of the crisis. ${ }^{27}$ As Figure 4 shows, France and Italy are, respectively, the countries with more and less pro-EU scrutiny sentiment. This is congruent to our argument if one believes France to have been less constrained and Italy to be more exposed to the crisis. But the plots in Figure 4 also suggest some flattening of the pro-scrutiny indicator in 2012, the lowest point of the Euro crisis. This is in line with the expectation that, at the peak of the Great Recession, when banks' liquidation and soaring deficits constrained the Euro countries, national parliamentarianschosetostay more quietaboutEU institutions, in order tolet them govern.

To be clear, we do not exclude that these patterns may be in part affected by party politics. However, after disaggregating the parliamentary debate data of Germany at the party level, we fail to observe striking differences in the way the terms in our dictionary are used or repeated. Descriptive figures in the Appendix indicate that the distribution of the key concepts is actually more uniform than not across the main parties, with only the exception of a few (namely 'mandate' and 'transparency', which the governing CDU uses more than the other representative parties). Based on this premise, we now turn to a systematic investigation of these mechanisms with a regression analysis, where the unit of analysis is each country across the months between September 2007 and May 2014.

\section{Estimation Strategy}

Our monthly data presents similarly stationary issues as the yearly data. We then stay consistent with the methodological discussion from the previous section and estimatelinear ECMs for the three Eurozone parliaments' data. We run models on two different outcome variables. The first outcome is Number of Parliamentary Debates, which measures the frequency of EU oversight debates in the parliamentary chambers of the Eurozone. The full model for this variable follows Equation 2:

$$
\begin{gathered}
\Delta \text { Debates }_{i t}=\alpha_{0}+\alpha_{1} \text { Debates }_{i t-1}+\beta_{1} \Delta \text { ECBRate }_{i t}+\beta_{2} \text { ECBRate }_{i t-1}+\beta_{1} \Delta \text { ttreekBond }_{i t}+ \\
\beta_{2} \text { ttreekBond }_{i t-1}+\beta_{3} \Delta \text { Debt }_{i t}+\beta_{4} \text { Debt }_{i t-1}+\beta_{5} \Delta \text { ECBRate }_{i t}{ }^{*} \Delta \text { Debt }_{i t}+\beta_{6} \text { ECBRate }_{i t-1}{ }^{*} \text { Debt }_{i t-1}+ \\
\beta_{5} \Delta \text { ttreekBond }_{i t}{ }^{*} \Delta \text { Debt }_{i t}+\beta_{6} \text { ttreekBond }_{i t-1}{ }^{*} \text { Debt }_{i t-1}+\beta_{7} \Delta \mathbf{X}_{i t}+\beta_{8} \mathbf{X}_{i t-1}+u_{i t} \quad \text { (Eq. 2) }
\end{gathered}
$$

\footnotetext{
${ }^{27}$ See a summary of the new pro-scrutiny indicator and the number of debates focused on EU institutions during the crisis broken down by country in the Appendix.
} 
The second outcome is Net Support for Scrutiny, which measures the overall pro-oversight sentiment among parliamentarians in the onset of debates. Weemploy equivalent models to Equation 2 for this outcome variable.

The suffix $i$ in Equation 2 indexes each of the analyzed countries, and $t$ indicates each month. In this framework, we estimate two separate proxies of crisis employed in similar analyses of the Euro crisis (Genovese et al. 2016). First is the action taken by the ECB. This is captured by the changes and levels of the ECB deposit rate, which is the interest national banks earn after depositing excess funds in the ECB overnight, hence the interest they pay for otherwise circulating money. Second is the immediate and long-term effects of Greek (10-year) bond yield, which were palpable indicators of Eurozone dysfunction. We expect these variables to be especially powerful at explaining the timing of and preferences in EU oversight debates when interacted with debt, which we measure with Eurostat data of Debt to GDP ratio. Following our conjecture, we expect the deepening of the crisis to refrain parliaments to offer space for EU oversight debates. This should especially hold for moments in which the countries became increasingly involved with fiscal debt. So, we expect the interaction coefficients for the Number of Parliamentary Debates models to be negative. At the same time, we anticipate that - for the debates that did occur amidst the recent years - the Euro crisis and the growing national debts increased parliamentarians' preference for EU scrutiny. This implies that the interaction coefficients from Net Support for Scrutiny models should be positive and significant.

We estimate these models controlling for a number of additional factors, $\mathbf{X}$, that are consistent to the control variables in the previous analysis. Inflation is the monthly rate of price stability from Eurostat, and Government ideology is the yearly cabinet composition measure that we recode based on the month when governments changed.

\section{Results}

Our models yield the results reported in Table 3. Model 1 is an unconditional specification with the partial effects of our economic variables on Number of Parliamentary Debates. We find that the most consistent and meaningful predictor is the ECB deposit rate, especially its short-term change. This is reasonable if one believes that the deposit rate constituted a crucial management action to solve the crisis. Evidently, this mechanism diffused the concerns of EU crisis management, and overall decreased the likelihood of EU oversight 
debates. Noteworthy is the positive coefficient of the Greek bond yield $t_{-1}$, which suggests that some concerning aspects of the bond markets offered opportunities for parliamentary debates overall. However, the coefficient is small and the long-term multiplier (compound with the short-term effect of the Greek bond) is insignificant. The level of Debt to $G D P$ is negatively associated to debate occurrences, but the effect is also marginal.

More crucially, the 'deep' crisis characterized by the interaction of the crisis measures and Debt to GDP in Model 2 shows the expected effect we hypothesized. At least with respect to the Greek bond spread, we find that a high debt in the midst of crisis has a negative and statistical significant effect on the frequency of oversight debates in national Eurozoneparliaments. Butdespitetheattempttosuppress thecontrol of executivedecisions in the EU during the crisis, we have already indicated that some topical debates did occur. So did national parliamentarians use these debates to express public concerns with EU supranational power and the necessity for supervisory reforms?

Our models of Net Pro-Scrutiny Sentiment suggest so, at least for the moments when the crisis motivated member states to increase debt as a primary crisis management compensation strategy. The unconditional specification in Model 3 presents little evidence of the impact of the crisis on pro-scrutiny positions, but the interactions in Model 4 show clearly that, when relevant debates occurred (dropping all the zeros for debates that did not take place), EMU parliaments may eventually demand what parliaments in monetarily sovereign countries obtain: more EU scrutiny when debt increases and the pressure of the crisis reaches its climax.

The findings are robust to a number of sensitivity tests that we report in the Appendix. The results for the Number of Parliamentary Debates are smaller but substantively equivalent if we employ the relative instead of the absolute frequency to account for how debating varies across states and other (e.g. seasonal) patterns of debates. The effects also persist if we include dummies for the introduction of EU institutional measures implemented at the EU level during the crisis - namely, the introduction of the EFSF (June 2010), the expansion of theEFSF (July 2011), and the establishment of the European Stability Mechanism (February 2012). We also experiment with bootstrapping regressions to at least partially address the measurement issues in our sentiment coding. Bootstrapping in this context means that randomly drawing data from our dataset, in some estimations the zeros (false positives) may be appear more often than in others. The results report relatively strong results across 
different random data draws. Finally, the results are robust to estimating the models in a fixed-effect fashion, and are not sensitive to including a pro-EU integration/skepticism indicator as a control variable.

In sum, the evidence suggests that, during the Euro crisis, national parliaments limited debating the EU handling of the crisis until this was concretely managed. In less burdensome times, and when debates took place, national parliaments tended to focus on more EU scrutiny, especially if increasing fiscal debt was required.

\section{Conclusion}

Integration skeptics have highlighted since decades the difficulties the EU has in reforming itself. According to Scharpf (1988) for instance, the organization finds itself in a joint decision making trap' as there will always be governments that profit from the current status quo. This renders it impossible to change the rules of the game. Although similarly grim predictions were made after the onset of the Eurozone crisis, forecasts about the supposed inability of the EU to react to crises have overlooked that substantial institutional reforms have frequently been initiated in the wake of economic stress. The gloomy evaluations also do not address the puzzling variety in which the member states have reacted to EMU crisis. This article proposes a political economy framework to understand how economic shocks can change demands for reform in international organizations like the EU, and under what conditions they can undermine or solidify them.

We show that the economic policies designed to maintain the credibility of domestic institutions have important implications for the way parliaments position themselves towards the EU in the course of a financial crisis. Focusing on the different policy options across EU member states inside and outside the Eurozone, we argued that the latter are much more flexible and reactive in adopting EU oversight institutions than the former, at least in the short run. ${ }^{28}$ However, wealso maintained that the constraints that restrict theparliamentary adoption of EU oversight mechanisms in the Eurozone do not refrain the public to request

\footnotetext{
${ }^{28}$ Other studies have pointed out that some Eurozone parliaments did indeed gain additional participation rights, but they did so after 2010, for example in the in new rescue mechanisms. Indeed a number of publications emphasize the increase in power of especially the German Bundestag. These reforms may have lagged some time, and probably were affected by other important factors, e.g. prospects of new EU accession, new treaties or the changing forms of partnership with Brussels. Our study does not seek to rival these alternative explanations nor to make inference on long-term political trends.
} 
a debate on EU supervision. We then theorized that during the Eurozone crisis national parliaments actually allowed for a debate leaning to more EU scrutiny unless they were too exposedandvulnerabletothecrisis.

We propose two different empirical strategies to test our theoretical argument. On the one hand, an analysis of varying institutional responses of EMU and non-EMU countries to crises shows that non-EMU countries were more reactive in increasing oversight institutions, especially when affected by fiscal concerns. On the other hand, a new dataset of fine- grained parliamentary debates in three central Eurozone countries indicate that, while short-term reactions to the global recession may have lacked (or lagged) in the Eurozone, at least rhetorically the national parliaments of these EMU states did respond along the lines of the conjecture put forward in the theory. Surely the analyses come with some caveats; for example, given that the data on institutional reforms in the first empirical analysis ends in 2010 and the debate data in the second analysis covers the time period until 2014, contrasting reform and debate activity is difficult. Nevertheless, we think that, in the aggregate, the evidence put forward indicates the reasons why smoke did follow the fire of the recent crisis across the European continent - although in different forms and with different timing.

More broadly, our argument complements other studies of national parliamentary behavior in EU member states, although it provides an additional angle to the challenges of European integration by focusing on the structural economic constraints of parliaments' control of the EU. The article also provides a political economy explanation for why parliamentary democracy in the Eurozone was put so vigorously under pressure since the financial crisis, but was also largely resilient by strategically decompressing public concerns via parliamentary debates. Finally, our findings suggest that, despite a sound concern of EU unresponsiveness (DeVries 2018; Schneider 2018), democratic demands for more transparent monitoring of the EU ultimately were championed across the European continent, including the Eurozone. While these parliamentary reactions may still not have been successful at cushioning a new wave of Euroskeptic populist parties, they may have sustained some trust in democracy among the European electorate (Schraff and Schimmelfennig 2019) and its domestic institutions. 


\section{References}

Abbas, S. M. Ali, N. Belhocine, A. El-Ganainy, \& M. Horton. 2011. 'Historical Patterns and Dynamics of Public Debt. Evidence from a New Database.' IMF Economic Review, 59(4).

Alesina, A., and Giavazzi, F. 2013. Fiscal Policy After the Financial Crisis. U of Chicago Press. Alesina, Alberto, and Allen Drazen. 1991. 'Why Are Stabilizations Delayed?' American Economic Review, 81(5): 1170-1188.

Alesina, Alberto, Dorian Carloni and Giampaolo Lecce. 2011. The Electoral Consequences of Large Fiscal Adjustments. NBER 17655.

Armingeon, K., and Ceka, B. 2014. 'The Loss of Trust in the European Union during the Great Recession since 2007: The Role of Heuristics from the National Political System.' European Union Politics, 15(1), 82-107.

Armingeon, Klaus, Romana Careja, et al. 2011. Comparative Political Data Set III 19902009. Institute of Political Science, University of Berne.

Armingeon, Klaus and Baccaro, Lucio. 2012. 'Political Economy of the Sovereign Debt Crisis: The Limits of Internal Devaluation.' Industrial Law Journal, 41(3): 254-275.

Auel, K. and Christiansen, T. 2015. After Lisbon: National Parliaments in the European Union. West European Politics, 38:2, 261-281.

Auel, K., Eisele, O. and Kinski, L. 2018. What Happens in Parliament Stays in Parliament? Newspaper Coverage of National Parliaments in EU Affairs. Journal of Common Market Studies, 56(3): 628-645.

Auel, K. and Höing, O. 2014. 'Parliaments in the Euro Crisis: Can the Losers of Integration Still Fight Back?' Journal of Common Market Studies, 52(6):1184-93.

Auel, K. and Raunio, T. 2014. Debating the State of the Union? Comparing Parliamentary Debates on EU Issues in Finland, France, Germany and the UK. Journal of Legislative Studies, 20(1).

Bernhard, William, Broz, J. Lawrence and Clark, William Roberts. 2002. 'The Political Economy of Monetary Institutions.' International Organization, 56(4): 1-31.

Bodea, C. and Hicks, R. 2015. 'Price Stability and Central Bank Indepen- dence: Discipline, Credibility and Democratic Institutions.' International Organization, 69(1).

Bordo, Michael D., and Anna J. Schwartz. 1997. Monetary Policy Regimes and Economic Performance: The Historical Record. NBER Working Paper.

Broz, Lawrence J. 2002. 'Political System Transparency and Monetary Commitment Regimes.' International Organization, 56(4): 861-887.

Closa, Carlos and Maatsch, Aleksandra. 2014. In a Spirit of Solidarity? Justifying the European Financial Stability Facility (EFSF) in National Parliamentary Debates. Journal of Common Market Studies, 52(4): 826-842. 
Cukierman, Alex. 1992. Central Bank Strategy, Credibility and Independence: Theory and Evidence. Cambridge, MA: MIT Press.

De Grauwe, P. 2011. Only a more active ECB can solve the Euro crisis. Center for European Policy Studies.

De Vries, Catherine. 2018. Euroscepticism and the Future of European Integration. Oxford University Press.

De Wilde, Pieter, and Raunio, Tapio. 2018. Redirecting national parliaments: Setting priorities for involvement in EU affairs. Comparative European Politics, 16(2), 310-329.

Drazen, Allan and Vittorio Grilli. 1993. The Benefit of Crises for Economic Reforms. American Economic Review, 83(3): 598-607.

Finke, Daniel, Thomas Koenig, Sven-Oliver Proksch, and George Tseblis. 2012. Reforming the European Union: Realizing the Impossible. Princeton University Press.

Finke, Daniel and Bailer, Stefanie. 2019. 'Crisis bargaining in the European Union: Formal rules or market pressure?’ European Union Politics, 20(1): 109-133.

Follesdal, Andreas and Simon Hix. 2006. 'Why there is a democratic deficit in the EU: A response to Majone and Moravcsik.' Journal of Common Market Studies, 44(3): 533-562.

Fasone, Cristina. 2014. European Economic Governance and Parliamentary Representation. What Place for the European Parliament? European Law Journal, 20(2): 164-185.

Foster, C. and Frieden, F. 2017. 'Crisis of Trust: Socio-economic determinants of Europeans' confidence in government.' European Union Politics, 18(4): 511-535.

Frankel, Jeffrey A. 2005. Mundell-Fleming Lecture: Contractionary Currency Crashes in Developing Countries. IMF Staff Papers, 52(2): 149-192.

Frieden, J. and Walter, S. 2017. 'Understanding the Political Economy of the Eurozone crisis', Annual Review of Political Science, 20: 371-90.

Genovese, F., Schneider, G. and Wassmann, P. 2016. 'The Eurotower Strikes Back: Crises, Adjustments, and Europe's Austerity Protests.' Comparative Political Studies. 49(7): 939967.

Giddens, A. 'In Europe's dark days, what cause for hope?' The Guardian, January 25. www . theguardian.com/world/2012/jan/25/anthony-giddens-europe-dark-days-hope?newsfeed=true

Giersch, Herbert. 1985. Eurosclerosis. Kiel Discussion Papers 112.

Gilbert, Mark F. 2004. Surpassing Realism: The Politics of European Integration Since 1945. Rowman and Littlefield Publishers.

Habermas, Jürgen. 2011. Zur Verfassung Europas. Ein Essay. Berlin: Suhrkamp.

Hagemann, S., Bailer S., and Herzog A. 2019. Signals to Their Parliaments? Governments' Use of Votes and Policy Statements in the EU Council. Journal of Common Market Studies, 
$57(3)$.

Hallerberg, Mark, Marzinotto, Benedicta and Wolff, Guntram B. 2018. Explaining the evolving role of national parliaments under the European Semester, Journal of European Public Policy, 25:2, 250-267.

Hooghe, Liesbet, and Gary Marks. 2009. 'A Postfunctionalist Theory of European Integration: From Permissive Consensus to Constraining Dissensus.' British Journal of Political Science, 39(1): 1-23.

Hsu, Sara. 2013. Financial Crises, 1929 to the Present. Edward Elgar Publishing, pp.1189.

Karlas, Jan. 2012. National Parliamentary Control of EU Affairs: Institutional Design after Enlargement. West European Politics, 35:5,1095-1113.

Kuhn, T. and Stoeckel, F. 2014. When European integration becomes costly: the Euro crisis and public support for European economic governance. Journal of European Public Policy, 21(4).

Laffan, Brigid. 2014. Testing Times: The Growing Primacy of Responsibility in the Euro Area, West European Politics, 37:2, 270-287.

Laeven, Luc and Fabián Valencia. 2012. Systemic Banking Crises Database: An Update. IMF Paper 12/163.

LeDuc, Lawrence, and Pammett, Jon H., 2013. 'The fate of governing parties in times of economic crisis'. Electoral Studies, 32 (3), 494-499.

Maatsch, Aleksandra. 2017. Effectiveness of the European Semester: Explaining Domestic Consent and Contestation. Parliamentary Affairs, 70 (4), 691?709.

Mair, P. 2009. Representative versus responsible government. MPIfG working paper, 09/8.

Majone, Giacomo. 1998. Europe's 'Democratic Deficit': The Question of Standards. European Law Journal, 4(1): 5-28.

Malang, Thomas. 2019. 'Why national parliamentarians join international organizations.' Review of International Organizations, Forthcoming.

Moravcsik, Andrew. 2002. In Defence of the 'Democratic Deficit': Reassessing the Legitimacy of the European Union. Journal of Common Market Studies, 40(4): 603-34.

Moravcsik, Andrew. 2012. Europe After the Crisis: How to Sustain a Common Currency. Foreign Affairs, 91: 3.

O’Brennan, J. and Raunio, T. 2007. National parliaments within the enlarged European Union: from 'victims' of integration to competitive actors?. Routledge.

Puntscher Riekmann, Sonja and Wydra, Doris. 2013. 'Representation in the European State of Emergency: Parliaments against Governments?' Journal of European Integration, 35(5).

Rauh, Christian. 2018. Validating a sentiment dictionary for German political language - a workbench note. Journal of Information Technology and Politics, 15:4, 319-343. 
Rauh, Christian and de Wilde, Pieter. 2018. 'The Opposition deficit in EU accountability: Evidence from over 20 years of plenary debate in four member states.' European Journal of Political Research, 57(1): 194-216.

Rocabert, J., Schimmelfennig, F., Crasnic, L. and Winzen, T. 2019. 'The rise of international parliamentary institutions: Purpose and legitimation.' Review of International Organizations.

Rose R. 2014. Responsible Party Government in a World of Interdependence. West European Politics, 37.

Rodrik, Dani. 1996. 'Understanding Economic Policy Reform.' Journal of Economic Literature, 34:(1): 9-41.

Ruiz-Rufino, Ruben \& Alonso, Sonia. 2017. Democracy without choice: Citizens' perceptions of government autonomy during the Eurozone crisis. European J Political Research, 56.

Scharpf, Fritz W. 1988. 'The joint-decision trap: Lessons from German federalism and European integration'. Public Administration, 66(3): 239-278.

Scharpf, Fritz W. 2011. Monetary union, fiscal crisis and the preemption of democracy. (MPIfG discussion paper, 11/11). Cologne: Max-Planck-Institut für Gesellschaftsforschung.

Schimmelfennig, F. 2015. 'Liberal intergovernmentalism and the Euro area crisis.' Journal of European Public Policy, 22(2):177-195.

Schneider, Christina. 2018. The Domestic Politics of International Cooperation. Oxford Research Encyclopedia of Politics.

Schraff, Dominik and Frank Schimmelfennig. 2019. 'Eurozone Bailouts and National Democracy: Detachment or Resilience?’ European Union Politics, 20:4.

Senniger, Roman. 2019. 'Institutional change in parliament through cross-border partisan emulation.' West European Politics, forthcoming.

Spoon, Jae-Jae and Williams, Christopher. 2017. It takes two: how Eurosceptic public opinion and party divisions influence party positions. West European Politics, 40(4): 741-762.

Tarlea, S., Bailer, S. Degner, H. et al. 2019. 'Explaining governmental preferences onEconomic and Monetary Union Reform.' European Union Politics, 20:1, 24-44.

Wasserfallen, Fabio, Dirk Leuffen, Zdenek Kudrna, \& Hanno Degner (2019) Analysing Decision-Making during the Eurozone Crisis with New Data. European Union Politics, 20(1).

Winzen, Thomas. 2012. 'National parliamentary control of European Union affairs: a crossnational and longitudinal comparison.' West European Politics, 35(3): 657-72.

Winzen, Thomas. 2017. Constitutional Preferences and Parliamentary Reform: Explaining National Parliaments' Adaptation to European Integration. Oxford University Press.

Wonka, Arndt. 2016. The party politics of the Euro crisis in the German Bundestag: frames, positions and salience. West European Politics, 39(1):125-144. 
Figure 1: Trends on the Adoption of EU Oversight Institutions in Selected Countries
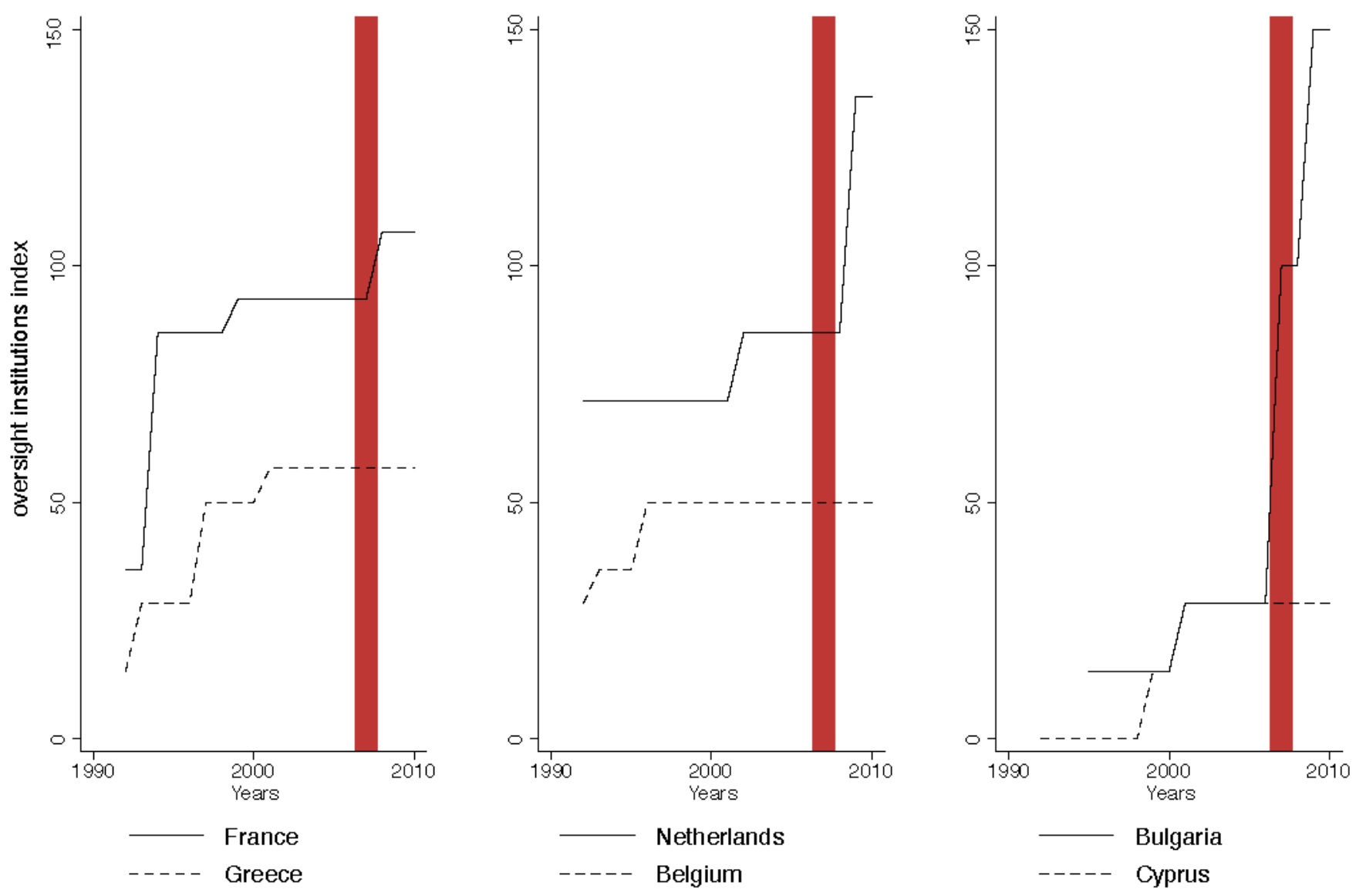

Lines are the country-specific trends on Winzen's rescaled institutional oversight index. The red bar indicates the beginning of the Great Recession (2008) that led to the Euro crisis; it does not refer to country-specific crises (Bulgaria, for example, did not undergo a crisis according to Laeven and Valencia, 2012). 
Figure 2: Parliamentary Debates on the EU during the Euro crisis

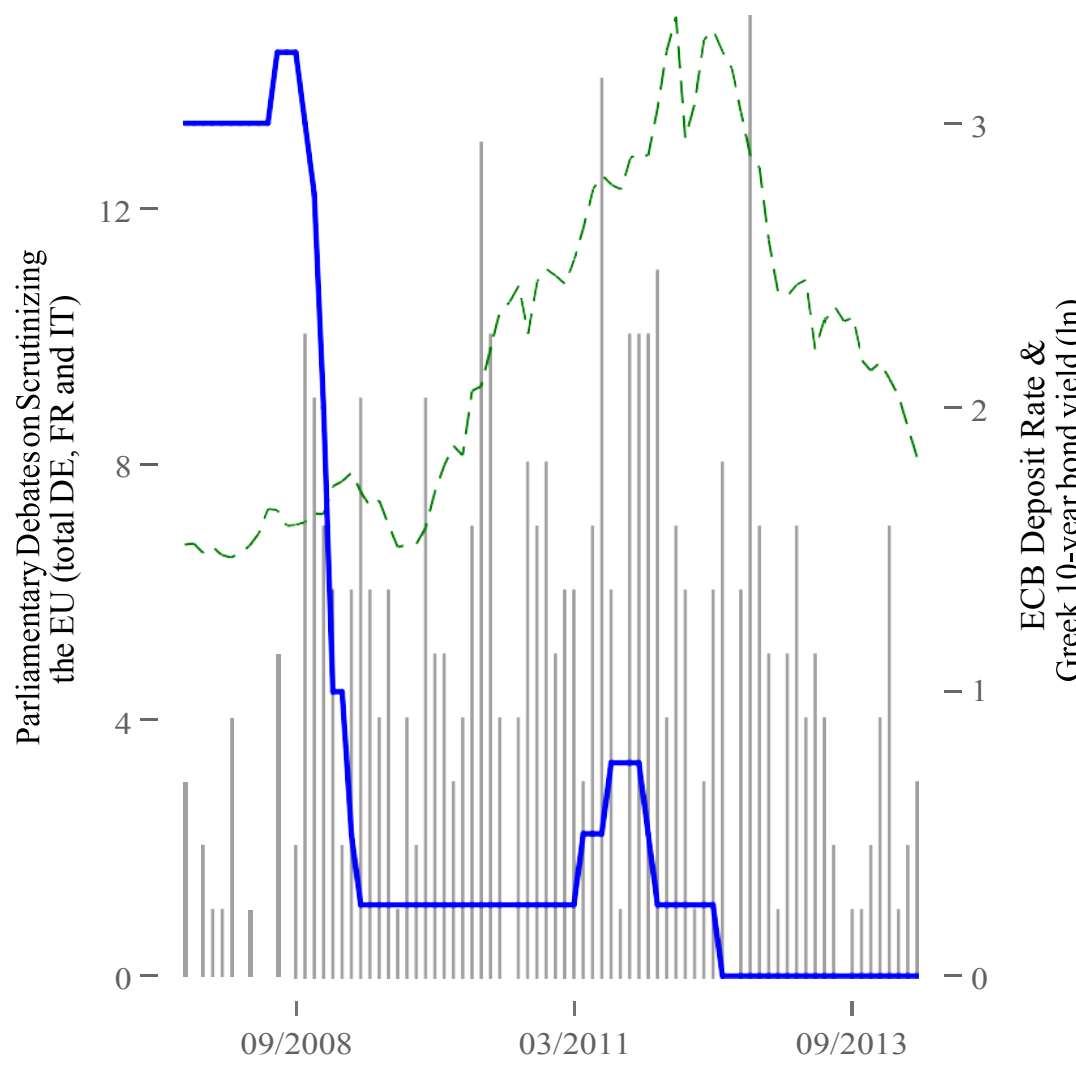

Parliament Debates (DE, FR and IT)

- - Greek 10-year bond yield (ln)

ECB Deposit Rate

France

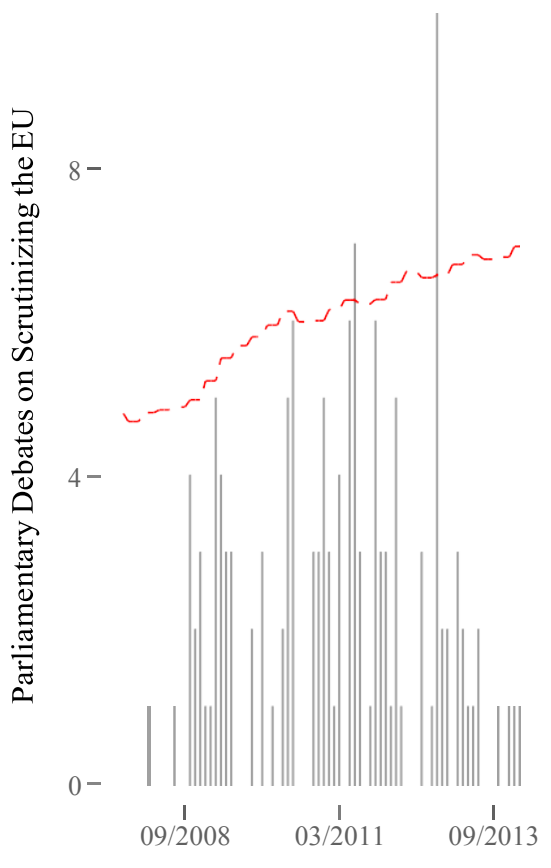

Germany

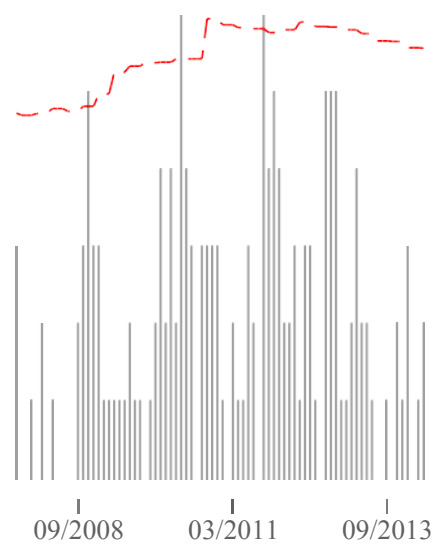

Italy

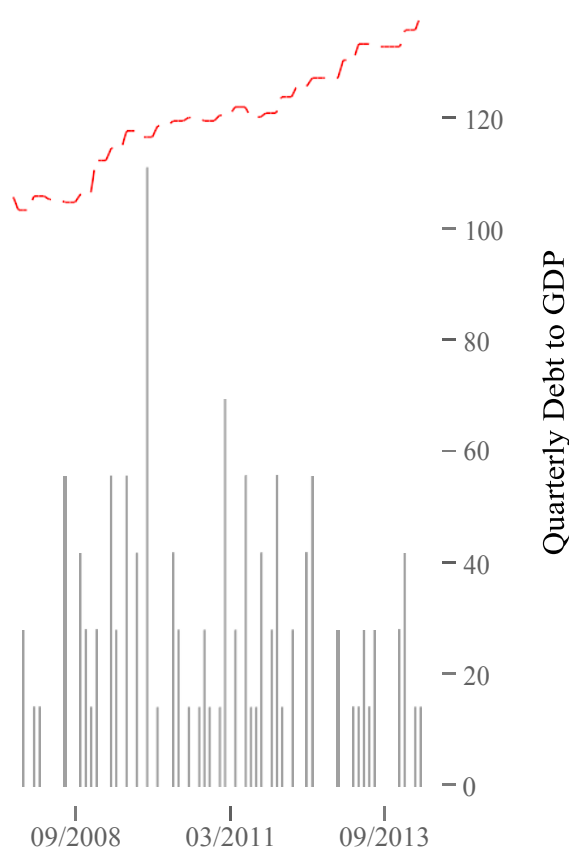

Parliament Debates $\quad--$ Quarterly Debt to GDP

Counts of parliamentary debates on the EU (grey bars) for France, Germany and Italy. The data is aggregated at the month level in all graphs, and for the three countries in top graph. See main text for data sources for the parliamentary meetings. ECB deposit rate retrieved from the ECB data archives. Greek 10year bond yields and national debt to GDP ratios collected from Eurostat. 
Figure 3: Pro- and Anti-Scrutiny Sentiment in Parliamentary Debates: Selected Key Words

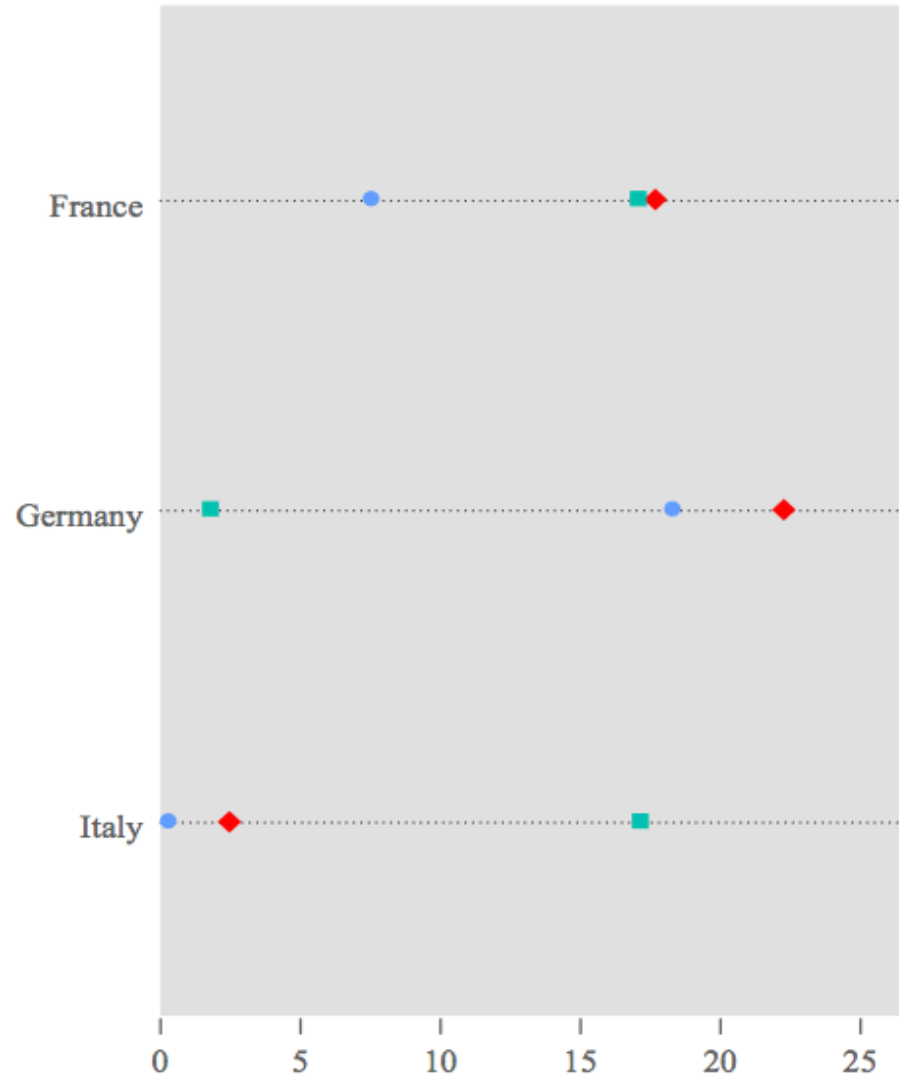

\author{
Selected Pro Scrutiny Key Words \\ - Scrutiny \\ - Oversight \\ - Nat'l Accountability
}

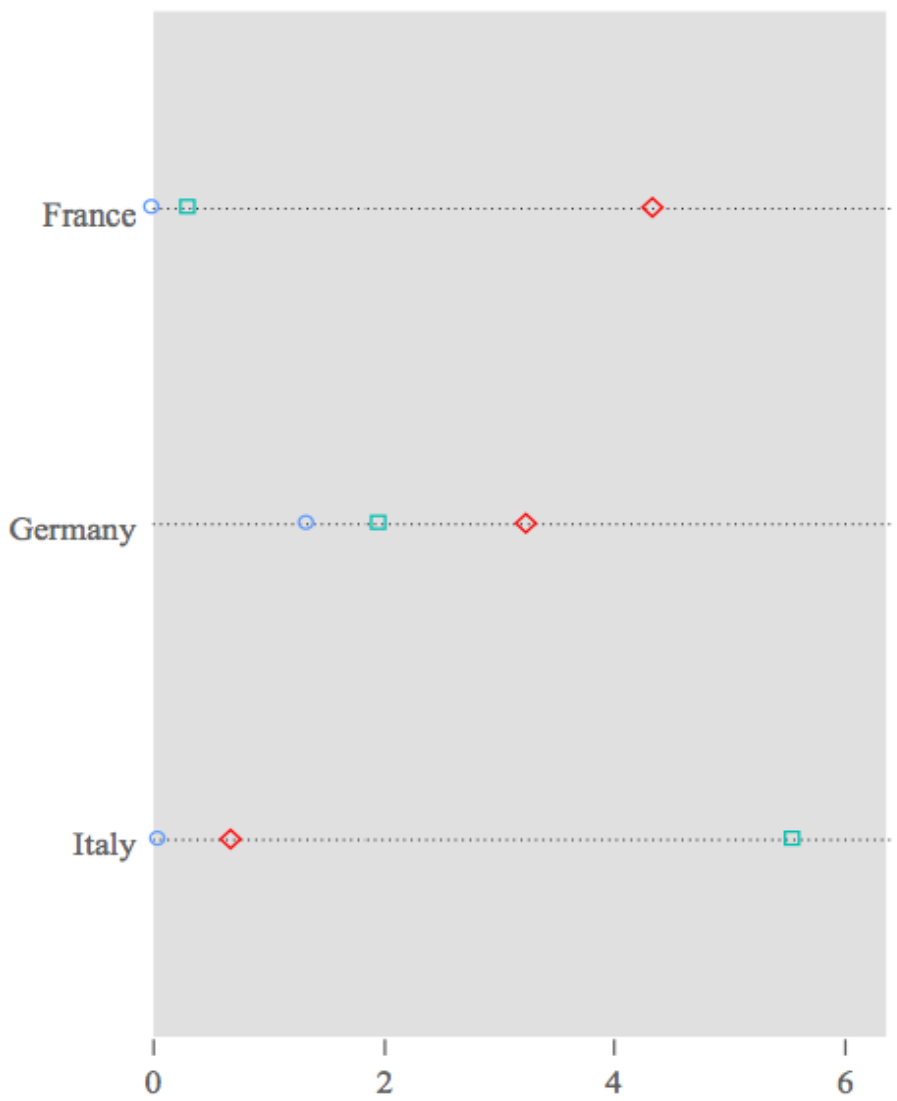

Selected Anti Scrutiny Key Words

$\diamond$ EU Autonomy

- EU Centralization

$\square$ Suprant'l competence

The plots show the raw frequencies of selected pro- and anti-scrutiny words as collected in the texts of the French, German and Italian parliamentary debates (2007-2014). 
Figure 4: The Great Recession and Variation of Support for Scrutiny of EU institutions



The plot shows the variation of pro-scrutiny sentiment as recorded in the collected texts of the French, German and Italian parliamentary debates (black lines). The graph also shows the Greek 10-year bond yields and the ECB deposit rate as the two main indicators of the Euro crisis. 
Table 1: Financial Crises and the Momentum for Institutional Reform in the EU

\begin{tabular}{|c|c|c|c|}
\hline Financial Crisis & $\begin{array}{c}\text { Symptoms } \\
\text { of the Crisis }\end{array}$ & $\begin{array}{c}\text { Political response } \\
\text { (competence arrangements) }\end{array}$ & $\begin{array}{c}\text { Economic response } \\
\text { (technocratic arrangements) }\end{array}$ \\
\hline $\begin{array}{c}\text { 1971-76: End of Bretton } \\
\text { Woods and first oil shock }\end{array}$ & $\begin{array}{c}\text { Malfatti } \\
\text { Commission }\end{array}$ & $\begin{array}{c}\text { Paris Summit and } \\
\text { EA elections (1974) }\end{array}$ & $\begin{array}{c}\text { Currency 'snake' } \\
\text { (1972) }\end{array}$ \\
\hline $\begin{array}{c}\text { 1979-84: Second oil } \\
\text { shock }\end{array}$ & 'Eurosclerosis' & $\begin{array}{c}\text { Court of Justice and EP } \\
\text { empowerment (1980) }\end{array}$ & $\begin{array}{c}\text { EMS/ECU (1979) } \\
\text { and SEA (1984) }\end{array}$ \\
\hline $\begin{array}{c}\text { 1987-91: US loan crisis } \\
\text { and 'Black Monday' }\end{array}$ & $\begin{array}{c}\text { British } \\
\text { veto }\end{array}$ & $\begin{array}{c}\text { New Intergovernmental Confe- } \\
\text { rences launched (1990) }\end{array}$ & $\begin{array}{c}\text { Delors EMU } \\
\text { Report (1989) }\end{array}$ \\
\hline $\begin{array}{c}\text { 1992-97: Oil price spike and } \\
\text { UK 'Black Wednesday' }\end{array}$ & $\begin{array}{c}\text { Santer } \\
\text { Commission }\end{array}$ & $\begin{array}{c}\text { Codecision introduced (1992) } \\
\text { and extended (1997) }\end{array}$ & $\begin{array}{c}\text { Maastricht Treaty } \\
\text { (1992) and ECB (1998) }\end{array}$ \\
\hline 2007-12: US subprime & European & Empowered national & EMU decision \\
mortgage and & Stability & parliaments (Lisbon Treaty, & 2009) \\
Eurozone crisis & Mechanism & \multicolumn{2}{c}{ (2012-) } \\
\hline
\end{tabular}

The table summarizes the historical relationship between financial crises and reactions in the EU in the form of political responses, on the one hand, and economic responses, on the other. 
Table 2: Financial Crises and the Adoption of EU Oversight Institutions

\begin{tabular}{|c|c|c|c|c|}
\hline & \multicolumn{4}{|c|}{$Y:$ Oversight Institutions $\delta$} \\
\hline & \multicolumn{2}{|c|}{$\begin{array}{l}\text { Monetarily independent states, } 1950 \mathrm{~s}-2010 \\
\text { (1) }\end{array}$} & \multicolumn{2}{|c|}{$\begin{array}{l}\text { EMU states, } 1995-2010 \\
(3)\end{array}$} \\
\hline Oversight Institutions $_{t-1}$ & $\begin{array}{l}-0.12 \\
(0.027)\end{array}$ & $\begin{array}{l}-0.12 \\
(0.027)\end{array}$ & $\begin{array}{l}-0.030 \\
(0.015)\end{array}$ & $\begin{array}{r}-0.022 \\
(0.017)\end{array}$ \\
\hline Banking crisis $_{t-1}$ & $\begin{array}{l}-7.24^{* * *} \\
(2.35)\end{array}$ & $\begin{array}{l}-8.25^{* * *} \\
(2.29)\end{array}$ & $\begin{array}{c}4.59 \\
(5.44)\end{array}$ & $\begin{array}{c}18.5 \\
(11.6)\end{array}$ \\
\hline Banking crisis $\delta$ & $\begin{array}{l}-2.43^{* *} \\
(1.14)\end{array}$ & $\begin{array}{l}-2.96^{* * *} \\
(1.04)\end{array}$ & $\begin{array}{l}-1.14 \\
(0.97)\end{array}$ & $\begin{array}{l}-2.73 \\
(1.71)\end{array}$ \\
\hline Debt to $\mathrm{GDP}_{t-1}$ & $\begin{array}{r}-0.009 \\
(0.012)\end{array}$ & $\begin{array}{l}-0.012 \\
(0.012)\end{array}$ & $\begin{array}{c}0.001 \\
(0.016)\end{array}$ & $\begin{array}{c}0.005 \\
(0.014)\end{array}$ \\
\hline Debt to GDP $\delta$ & $\begin{array}{c}0.049 \\
(0.083)\end{array}$ & $\begin{array}{c}0.054 \\
(0.084)\end{array}$ & $\begin{array}{c}0.031 \\
(0.059)\end{array}$ & $\begin{array}{c}-0.056 \\
(0.085)\end{array}$ \\
\hline Government ideology $y_{t-1}$ & $\begin{array}{l}-0.19 \\
(0.29)\end{array}$ & $\begin{array}{l}-0.19 \\
(0.29)\end{array}$ & $\begin{array}{l}-0.14 \\
(0.20)\end{array}$ & $\begin{array}{l}-0.16 \\
(0.19)\end{array}$ \\
\hline Government ideology $\delta$ & $\begin{array}{l}-0.15 \\
(0.43)\end{array}$ & $\begin{array}{l}-0.13 \\
(0.44)\end{array}$ & $\begin{array}{l}0.084 \\
(0.24)\end{array}$ & $\begin{array}{r}0.096 \\
(0.27)\end{array}$ \\
\hline Inflation $_{t-1}$ & $\begin{array}{l}0.096^{* * *} \\
(0.021)\end{array}$ & $\begin{array}{l}0.098^{* * *} \\
(0.021)\end{array}$ & $\begin{array}{c}0.020 \\
(0.031)\end{array}$ & $\begin{array}{c}0.032 \\
(0.032)\end{array}$ \\
\hline Inflation $\delta$ & $\begin{array}{c}0.12 \\
(0.077)\end{array}$ & $\begin{array}{c}0.072 \\
(0.096)\end{array}$ & $\begin{array}{c}0.13^{*} \\
(0.075)\end{array}$ & $\begin{array}{l}0.12^{* *} \\
(0.058)\end{array}$ \\
\hline $\begin{array}{l}\text { Banking crisis } t_{t-1} \times \\
\text { Debt to GDP }{ }_{t-1}\end{array}$ & & $\begin{array}{c}0.023 \\
(0.030)\end{array}$ & & $\begin{array}{l}-0.18^{*} \\
(0.11)\end{array}$ \\
\hline $\begin{array}{l}\text { Banking crisis } \delta \times \\
\text { Debt to GDP } \delta\end{array}$ & & $\begin{array}{l}0.081^{* *} \\
(0.039)\end{array}$ & & $\begin{array}{c}0.24 \\
(0.16)\end{array}$ \\
\hline Constant & $\begin{array}{c}1.64 \\
(1.57)\end{array}$ & $\begin{array}{c}1.89 \\
(1.62)\end{array}$ & $\begin{array}{c}0.76 \\
(4.24)\end{array}$ & $\begin{array}{l}-1.30 \\
(3.94)\end{array}$ \\
\hline \multicolumn{5}{|l|}{$\underline{\text { Multiplier }}$} \\
\hline $\begin{array}{l}\text { Banking crisis } \times \\
\text { Debt to GDP }\end{array}$ & & $\begin{array}{l}0.738^{* *} \\
(0.305)\end{array}$ & & $\begin{array}{l}-4.46 \\
(4.03)\end{array}$ \\
\hline $\begin{array}{l}\mathrm{N}(\text { Countries }) \\
R^{2}\end{array}$ & $\begin{array}{c}299(23) \\
0.11\end{array}$ & $\begin{array}{c}299(23) \\
0.12\end{array}$ & $\begin{array}{c}156(13) \\
0.13\end{array}$ & $\begin{array}{c}156(13) \\
0.16\end{array}$ \\
\hline
\end{tabular}

The table reports linear ECM estimation coefficients of the outcome Oversight Institutions $\delta$. Robust standard errors in parentheses. ${ }^{*} \mathrm{p}<0.1,{ }^{* *} \mathrm{p}<0.05,{ }^{* * *} \mathrm{p}<0.01$. 
Table 3: The Great Recession and Parliamentary Debates on EU Oversight in the Eurozone

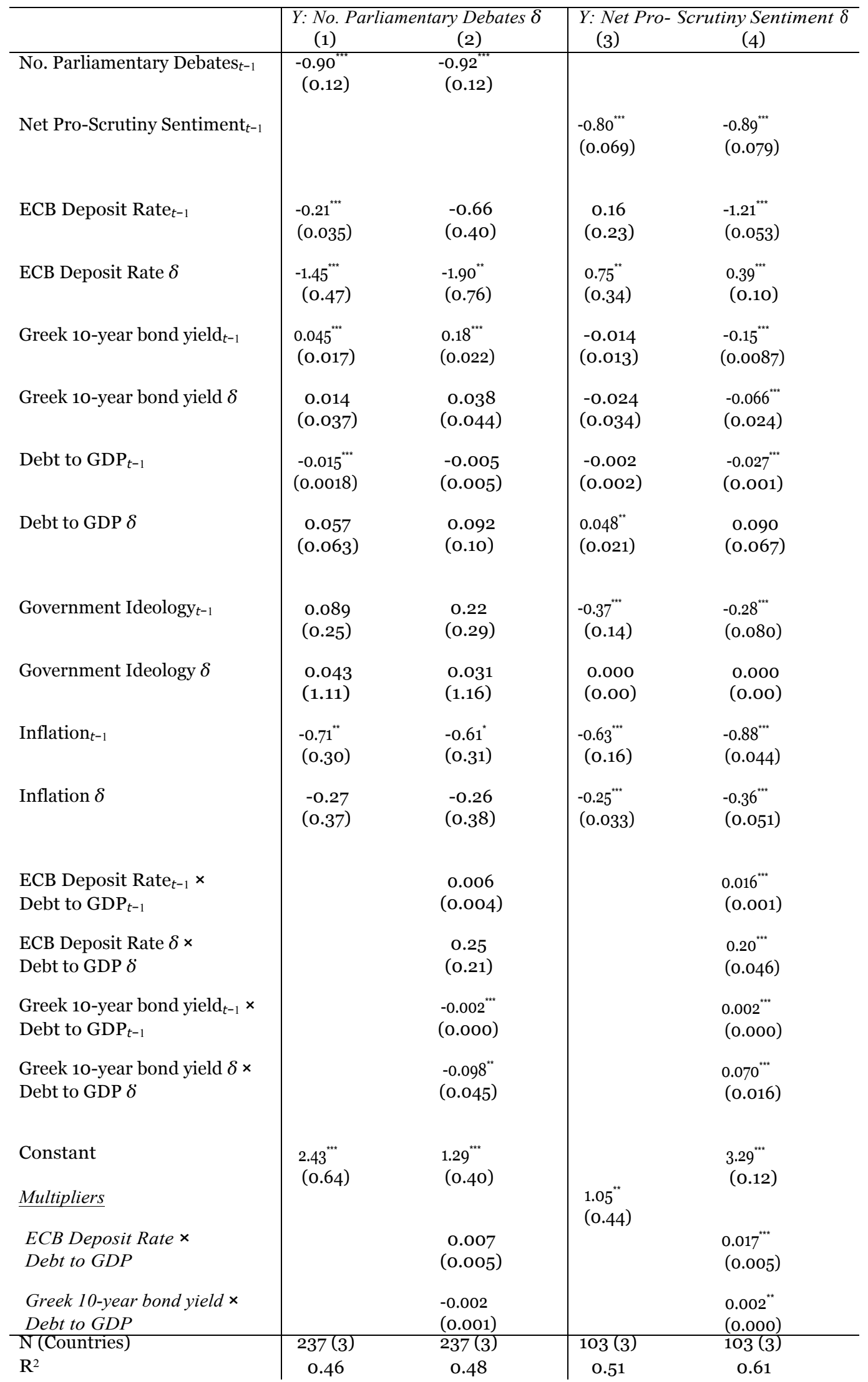

The table reports linear ECM estimation coefficients of the outcome Number Parliamentary Debates $\delta$ for models 1 and 2, and outcome Net Pro-Scrutiny Sentiment $\delta$ for models 3 and 4. Robust standard errors in parentheses. ${ }^{*} \mathrm{p}<0.1,{ }^{*} \mathrm{p}<0.05,{ }^{* *} \mathrm{p}<0.01$. 